\title{
Law and Finance in Transition Economies
}

Katharina Pistor, Martin Raiser and Stanislaw Gelfer

CID Working Paper No. 49

June 2000

Law and Development Paper No. 4

(C) Copyright 2000 Katharina Pistor, Martin Raiser and Stanislaw Gelfer and the President and Fellows of Harvard College

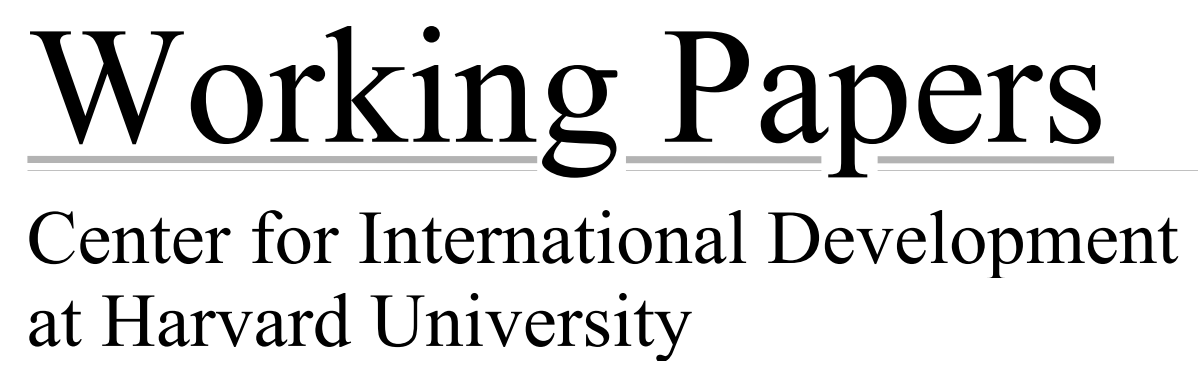




\title{
Law and Finance in Transition Economies
}

\author{
Katharina Pistor, Martin Raiser and Stanislaw Gelfer \\ CID Working Paper No. 49, June 2000 \\ Law and Development Paper No. 4
}

\begin{abstract}
This paper offers the first comprehensive analysis of legal change in the protection of shareholder and creditor rights in transition economies and its impact on the propensity of firms to raise external finance. Following La Porta et al. (1998), the paper constructs an expanded set of legal indices to capture a range of potential conflicts between different stakeholders of the firm. It supplements the analysis of the law on the books with an analysis of the effectiveness of legal institutions. Our main finding is that the effectiveness of legal institutions has a much stronger impact on external finance than does the law on the books, despite legal change that has substantially improved shareholder and creditor rights. This finding supports the proposition that legal transplants and extensive legal reforms are not sufficient for the evolution of effective legal and market institutions.
\end{abstract}

Keywords: shareholder and creditor rights, legal effectiveness, external finance, transition

JEL Classification Codes: G15, K22, K42, O16, P51

Katharina Pistor is a Fellow at the Center for International Development at Harvard University and Assistant Professor at the Kennedy School of Government, Harvard University.

Martin Raiser, Senior Economist, European Bank for Reconstruction and Development

Stanislaw Gelfer, Economist, Credit Suisse First Boston

We would like to thank Sorniza Dimitrova, Dmitri Gavriline and Violetta Bessenich for excellent reserach assistance. We also thank Philippe Aghion, Dan Berkowitz, Steven Fries, Klaus J. Hopt, Joel Hellman, Peter Sanfey, and seminar participants at the CEPR, EBRD, FOWI (Research Institute for East European Law) in Vienna, the Max Planck Institute for Foreign and Comparative Private Law in Hamburg, and the Stockholm Institute of Transition Economies (SITE) for helpful comments and suggestions on earlier drafts. The present draft has greatly benefited from comments by one anonymous referee and the editors of Economics of Transition. Funding for this project was provided by EBRD, as part of its policy studies programme on 'The Challenges of the Second Decade of Transition' and is gratefully acknowledged. 


\section{Law and Finance in Transition Economies}

Katharina Pistor, Martin Raiser and Stanislaw Gelfer

\section{Introduction}

The relevance of law for corporate governance has long been debated in the literature. Legal scholars have suggested that in comparison to competitive capital, product and managerial labour markets, the role of law is at best of secondary importance (Easterbrook and Fischel 1991) or even trivial (Black 1990). Recently, however, law has been elevated to an important determinant of stock market development (La Porta, Lopez-de-Silanes, Shleifer, and Vishny, 1997) and the banking sector (Levine 1998). Ironically, economists rather than lawyers have been the promoters of the new relevance theory of law for corporate governance. In a survey of corporate governance around the world, Shleifer and Vishny (1997) argue that the ownership structure of firms and the level of stock market development may be determined by the quality of shareholder protection. In countries with strong shareholder protection, investors can afford to take minority positions rather than controlling stakes. As a result, firms tend to have dispersed shareholders as owners and capital markets are rather liquid. By contrast, where shareholder rights are not well protected, investors will compensate for this deficiency by taking controlling stakes in a firm. The supply of finance through minority equity holders is therefore constrained by the extent of their protection under the law. By the same token, the provision of debt finance depends on the extent to which the law protects creditor rights vis-à-vis other claimants on a borrower's assets.

Empirical analyses suggest that the quality of the law on the books has high explanatory power for financial market development across countries (La Porta et al. 1997; 1998, hereinafter LLSV; and Levine, 1997). In a similar vein, industry level studies have established a close link between the legal protection offered to outside investors and the reliance of firms on outside funds to finance expansion (Carlin and Mayer 1999; Demirguc-Kunt and Maksimovic 1998; Rajan and Zingales 1998). While the importance of different types of external finance (equity versus debt) differs across industries, the existing literature concurs on the positive contribution of external finance to growth, and hence on the potential importance of legal arrangements that encourage such outside financing.

In this paper we provide a first attempt at applying these propositions to the transition economies. The motivation for this exercise is twofold. First, corporate governance problems loom large as explanations for the poor performance of the corporate sector in many transition economies (Stiglitz 1999). It is thus of interest to see whether these problems are related to a mismatch between the emerging ownership structure after privatisation and the protection of ownership rights provided by the law. Second, enterprises in transition arguably face particularly salient financing needs. The capital stock of many existing enterprises was rendered obsolete by the abolition of central planning and the resulting changes in relative prices, while at the same time cheap investment finance from the state largely

\footnotetext{
${ }^{1}$ For a critique of some of these arguments, see, however Bebchuk (1989) and Coffee (1989).
} 
disappeared. The extent to which firms are able to access external finance is therefore not only a potential indication of the quality of shareholder and creditor protection but also an important factor behind successful restructuring efforts.

Some scholars have recently argued that the classic corporate governance paradigm with its focus on the control of management by outside investors is too narrow to capture the specific problems of transition economies and other emerging markets (Berglöf and von Thadden 1999). In particular, small investors are unlikely to play an important role in these economies either today, or in the foreseeable future. In transition economies, the role of residual state ownership and the behaviour of blockholders such as the infamous Russian oligarchs suggest broadening the scope of analysis to reflect potential conflicts between a variety of stakeholders. Moreover, the historical experience of continental Europe emphasises the role of banks as providers of outside finance at the expense of broad equity markets at least until recently. For the less risky, capital intensive modernisation investments characteristic of lower levels of economic development, bank finance may be more appropriate - in turn suggesting a priority of creditor rights over shareholder rights in the process of legal reform (Carlin and Mayer 1999). While securities markets were effectively non-existent at the start of transition, a rudimentary banking system was generally in place. In line with this reasoning, the improvement of creditor rights might have priority over changes to the legal protection of minority shareholders.

In this paper, we take a first step towards broadening the scope of LLSV's analysis, by expanding their set of legal indicators. We include indices that capture the ability of the law to deal with a range of potential corporate governance conflicts, including those between shareholders and managers, minority shareholders and blockholders, shareholders and workers, and creditors and managers. We construct these indicators for each year of the transition. This enables us to analyse to what extent legal reforms have responded to specific challenges during the transition for instance emphasising the protection against blockholders over the protection against management, or emphasising creditor rights over shareholder rights. We find no such distinctive patterns. Rather it appears that legal reforms have been substantially driven by the desire to rapidly catch up with western standards in all areas and have been directly influenced by advice that often led to the wholesale transfer of western commercial laws to the transition economies.

In gauging the impact of the law on corporate governance, we concentrate on equity and debt finance. It can be argued that the protection of minority shareholders from blockholders is as important for the development of equity markets as is the protection of shareholders against management. The ability of managers to take operational decisions in the face of stakeholder resistance may also influence the confidence of investors and the development of equity finance. Collateral and bankruptcy rules are important for the provision of credit. Moreover, the development of external finance to some extent provides a useful summary indicator of improvements in corporate governance in the transition economies. Evidence from Russia's corporate sector reveals for instance that there is substantial scope 
for using the financing needs of enterprises in transition economies as an important lever to influence their corporate behaviour (Willer 1997).

For the law on the books to affect financial market development, however, law enforcement must be credible. Past experience with legal reforms suggests that where new laws were forced upon a judicial system unfamiliar with the underlying legal tradition and were not adapted to fit the specific local context, the effectiveness of the law suffered (Berkowitz, Pistor and Richard 1999; Pistor and Wellons 1999; Trubek and Galanter 1974). Trust in the law remained low and reliable enforcement by the state's legal institutions could not be guaranteed. Assessments of the legal environment in transition also tend to conclude that the quality of law enforcement is at least of equal importance to the extensiveness of the law (e.g. (EBRD 1997; 1998; 1999)). This evidence motivates one of the ways in which this paper extends the original approach of LLSV. We present various indicators of the effectiveness of the law in transition economies and find that cross-country variation in this regard is both more accentuated and seemingly more persistent than the variation in law on the book ${ }^{k}$. Our analysis suggests that the extent of previous exposure to modern commercial law is a key explanation for the variation in legal effectiveness. Furthermore, we provide a tentative analysis of the relative weights of the law on the books and the effectiveness of legal institutions for enterprise finance and find that in the experience of transition economies so far, the latter is the more important of the two.

The paper is structured as follows. Section 2 identifies the key problems of corporate governance in transition. Section 3 introduces the legal indices we use to assess the extent of shareholder and creditor rights' protection and reports the scope of legal change from 1992 through 1998 according to these indices. Section 4 supplements this analysis with an investigation of the effectiveness of legal institutions and its potential determinants, as opposed to the law on the books. Section 5 analyses the relation between legal change - of laws and legal effectiveness - and the development of financial markets in transition. Section 6 concludes.

\section{The problem of corporate governance in transition}

A useful point of departure for an analysis of corporate governance in transition economies is to think about the problems of corporate control under central planning. Two distinctive features of enterprise structures in centrally planned economies have a persistent influence during the transition (Kornai 1992). First, enterprises under central planning did not have to worry about raising external finance. Their budget constraints were soft, passive finance was provided under the central plan. Hence the concept of financial discipline or accountability was absent from the

\footnotetext{
${ }^{2}$ LLSV use similar variables to show that the effectiveness of legal institutions varies among legal families, but they do not compare variance between law on the books and law enforcement. Moreover the only explanation offered for variance in enforcement is the level of GDP. Our paper provides an important extension in showing the role of historical legacies of legal modernisation.
} 
socialist firm. Second, the state as the owner of most assets had a pervasive monitoring problem in trying to ensure that managers of socialist enterprises acted according to the targets set by the central plan. The two problems were closely interrelated. In the absence of the sanction of enforcing financial discipline by cutting off supplies and ultimately forcing an enterprise to close down, the problem of corporate control could never be resolved.

When central planning was abolished, the lack of external finance became a serious constraint on enterprises (Calvo and Coricelli 1992). As funding previously provided under the central plan was reduced or fully abolished, investment expenditures were slashed and capacity utilisation rates fell dramatically as a consequence of the lack of working capital. Enterprises reacted in a variety of ways. In the most successful cases, the cash flow generated by reorienting sales was sufficient for capital expenditures to be financed from retained earnings. In the majority of cases, however, enterprises resorted to involuntary borrowing from suppliers, workers and the state through the accumulation of payment, wage and tax arrears. The problem of substituting government finance with new sources of external finance is thus very much at the heart of the problem of corporate governance and restructuring in transition.

It should be noted that the reduction in directed state financing was often gradual rather than immediate. In several countries, most notably the CIS, the state continued to provide financial support to inefficient state enterprises channeled through state-owned commercial banks. This invariably led to extremely high inflation rates at the start of transition and the virtual disappearance of financial intermediation as a result (EBRD 1998). Related party lending and political intervention into credit allocation continue in many countries today, although macroeconomic stabilization policies have limited the extent to which soft finance is still available through an unreformed banking system. Yet, commercial bank credit has been slow to replace state financing, even where banking reforms have created a sound basis for financial intermediation. Commercial banks lack the confidence of depositors that would help to generate a sustainable funding base, and the skills necessary for prudent commercial banking. Equity finance was completely nonexistent at the start of transition and has been even slower to emerge than commercial bank lending.

Figures 1 and 2 give an indication of the degree of financial underdevelopment in the transition economies, even after 10 years of transition. They show the ratio of private sector credit to GDP and stock market capitalisation to GDP respectively in 1998, in relation to a worldwide benchmark, given by the level of per capita income. It is well established that financial depth tends to increase with rising incomes, and this is the case for transition economies as well. However, in particular the more wealthy transition economies are mostly far below their market economy benchmark with respect to both private sector credit and stock market capitalisation. While in the advanced transition countries, some increase in private sector credit has resulted in recent years from progress in reform and 
macroeconomic stabilisation (see below), the supply of funds to equity markets has almost entirely come from abroad, and has gone to a few utilities and Blue Chip companies.

Parallel to the reduction of state financing, economic reforms in transition also fundamentally altered the structure of ownership rights through privatisation. Privatisation methods have varied greatly across the region with potentially powerful implications for the availability of external finance. In a few countries - Hungary, Estonia, Latvia, and more recently and to a lesser extent Bulgaria and Kazakhstan - strategic sales to foreign investors have dominated among the large enterprises. In these countries, FDI has been an important source of external finance and a catalyst of corporate restructuring, albeit concentrated among the top tier of the corporate sector. However, most governments in the region were constrained in the design and implementation of privatisation by the power of incumbent managers, who had accumulated implicit control rights as a result of weak state monitoring under central planning. Privatisation often simply led to the explicit recognition of these control rights through the allocation of ownership titles to insiders (EBRD 1997). Further, domestic outside owners were initially dispersed and weak particularly where equal access voucher privatisation prevailed, such as in the Czech Republic. Against this background, external investors have been cautious in providing new capital, and restructuring efforts have been disappointing. Indeed, unchecked by owners and with little access to new funds to finance risky restructuring, managers have often faced incentives that were skewed towards asset stripping and expropriating minority shareholders (Black, Kraakman and Tarassova 1999; Coffee 1998).

Finally, despite the reduction in state financing, in many countries state intervention in corporate decision making remains very significant. A recent survey of over 3000 companies conducted by the EBRD in collaboration with the World Bank found that on average over 20 per cent of firms still faced regular state intervention in their corporate decision making. Notably, this included advanced transition economies such as Hungary and the Slovak Republic as well as laggards such as Belarus among the countries with the highest levels of state intervention. In many countries, governments retain golden shares in strategic companies, which potentially limit the commitment of outside owners to these firms.

At the risk of simplification, the problem of corporate governance in transition may thus be summarised as follows:

- External finance to replace state funding under the central plan is almost completely absent.

- Incumbent enterprise managers retain effective control rights even where privatisation has shifted ownership to outsiders.

\footnotetext{
${ }^{3}$ These results are confirmed by data from a survey of 3000 companies in transition economies conducted by the EBRD in collaboration with the World Bank in 1999 (World Business Environment and Enterprise Performance survey - BEEPS). The data reveal that on average $56 \%$ of total investment funds in all large firms have come from internal sources, $9 \%$ from the state, $9 \%$ from bank loans and $4.5 \%$ from equity issues. The remaining $20 \%$ are accounted for by other sources of finance, including friends, family, money-lenders, development finance from the government, suppliers credits and leasing arrangements (data on file with the authors).
} 
- The state retains influence over corporate decision making through a nexus of subsidies, regulatory favours, and tax arrears provided in exchange for residual control rights.

All three problems are closely intertwined. Enterprises will be unable to tap external sources of funds as long as they remain subject to extensive state intervention and/or insider control. Conversely, insider control will remain pervasive as long as potential investors are doubtful about the possible returns on their investments and refrain from acquiring substantial amounts of shares. And as long as enterprises are unable to survive on their own, the state will feel the need to ensure the survival at least of key enterprises. It is this nexus that motivates the attention to improvements in shareholder and creditor rights as a potential avenue for attracting additional outside funding into the corporate sectors of the transition economies. This in turn would start a virtuous circle of increased outsider control, accelerated restructuring, higher incentives for insiders to sell out, and less need for state intervention. It is with this motivation in mind that we turn to an examination of legal reforms in transition economies.

\section{Law on the books: shareholder and creditor rights in transition economies}

To analyse the scope of legal change in transition economies, we constructed a data base that codes shareholder and creditor rights for each year from 1990 to 1998. The year-end status is used for coding purposes. Because data for the earlier period are not complete, we use the period from 1992 to 1998 for most of our analyses. The coding system as well as individual country scores for all the indices constructed in this section can be found in the Appendix. A detailed analysis is provided in a companion paper to this one (Pistor 2000b).

The first legal database on shareholder and creditor rights for a large sample of countries was constructed by LLSV. It covers 49 countries, but does not include transition economies. A number of indicators were selected for assessing the extent of shareholder rights and creditor rights protection. Each country was assigned a score based on the existence or absence of provisions in their laws reflecting these indicators. The shareholder rights indicators selected by LLSV focus on provisions that protect minority shareholders in a corporation. Indicators of creditor rights target the protection of creditors in bankruptcy. The assumption that underlies this approach is that minority shareholder rights are crucial for the development of capital markets and the extent of ownership concentration of firms. Likewise, the protection of creditors in the critical situation of bankruptcy determines their willingness ex ante to lend money to a firm.

Our approach builds on, but extends the approach taken by LLSV. Following LLSV, we code selected legal provisions from the relevant statutes. However, in particular for shareholder rights, we greatly expand the type of

\footnotetext{
${ }^{4}$ While the issue of whether legal reforms have preceded financial deepening in the experience of market economies is not fully resolved, recent evidence gives some confidence on the direction of causality (Levine 1997; Levine and Zervos 1996); (Demirguc-Kunt and Maskimovic 1998).
} 
indicators included in the analysis. The reason is that minority shareholder protection is only one of the objectives of corporate law. Legislatures may pursue other objectives than furthering the development of capital markets and this alone does not necessarily imply that the law is a bad law. Corporate statutes tend to balance different interests and different strategies of various stakeholders of the firm. In addition to protecting minority shareholders against managers, they also protect minority shareholders against blockholders. Moreover, different statutes may offer different strategies for the protection of rights. Some may rely more on internal control rights, while other may favour exit as an enforcement option. Finally, the focus on shareholder rights seems to be too narrow even when the primary concern is the performance of stock markets. In a critique of the approach taken by LLSV, Pistor (2000a) and Coffee (1999c) argue that other types of rules may be equally important for stock market performance or serve as functional substitutes (Coffee 1999a). In particular, they point to the importance of securities regulations that protect the broader community of investors rather than the shareholders of a particular firm, and which are enforced by a state agency, not individual shareholders. ${ }^{\text {G }}$ With respect to creditor rights, we agree with LLSV that the role of creditors in bankruptcy is crucial. However, as discussed further below, some indicators suffer from a US bias. Moreover, the indicators presuppose the existence of legal provisions on security interests, which may not be taken for granted in transition economies.

For this broader analysis of shareholder rights in transition economies, we use a total of 27 indicators to construct six indices with equal weight given to each component indicator. To characterise the protection of the rights of minority shareholders, we use the anti-director rights index constructed by LLSV - referred to as LLSVsh. To capture the potential variations in the mechanisms of control and the allocation of control rights, we create five additional indices called VOICE, EXIT, ANTIMANAGE, ANTIBLOCK, and SMINTEGR. Exact definitions are provided in Appendix 1.

LLSVsh includes voting and litigation rights, as well as additional procedural rules for minority shareholders to voice their discontent, i.e. by calling an extraordinary shareholder meeting. It also includes the right of existing shareholders to acquire newly issued shares before they are offered to others, which enables them to prevent the dilution of their stake (pre-emptive rights). Most of these rights are targeted at management, but some could also be used against blockholders. Moreover, no distinction is made between different strategies for enforcing these rights. Yet, the strategy chosen for controlling managers may turn out to be crucial for the effectiveness of control. ${ }^{\square}$

\footnotetext{
${ }^{5}$ A similar point is made by Glaeser, Johnson and Shleifer (2000).

${ }^{6}$ The clear distinction between chapter 7 and chapter 11 procedures in the U.S. bankruptcy code, which informs the variable asking whether creditors have to give their consent before entering reorganisation or liquidation procedures, is less known in other jurisdictions.

${ }^{7}$ For a discussion of alternative control strategies used by voucher investment funds in Russia, see Frydman, Pistor, and Rapaczynski (1996). They suggest that hands on control mechanisms (voice) may be more important for developing stock markets than the ability of investors to sell their shares (exit). Interestingly, the results of LLSV show that this may be the case more generally. For a discussion of this point see Pistor (2000b).
} 
The corporate governance literature commonly distinguishes between 'voice' and 'exit' as the two alternative strategies shareholders may invoke to assert their control over company management (Coffee 1991; Hirschman 1970). Voice refers to mechanisms of internal control mostly through voting and information rights. The indicators we use include the shareholders' rights to hire and fire managers, judicial recourse, and quorum requirements for decision making in particular with respect to those decisions that may affect the value of the company. Exit means that shareholders may liquidate their holdings by selling their shares in case they are not satisfied with the way a company is managed.

These two control mechanisms are protected by different legal rules. Most of the LLSVsh indicators are legal rules that protect 'voice'. Our VOICE index includes all of the LLSVsh variables, as well as other control variables, which may, but do not have to, be specifically targeted at minority shareholders. Additional indicators used for the VOICE index are: the right of minority shareholders to call an audit commission (a special body in addition to the company board(s) in charge of reviewing the books); a minimum quorum requirement for a shareholder meeting to take binding decisions; super-majority requirements for adopting decisions that affect the existence of the corporation in its current form (including amendments of the charter, the liquidation of the company, or mergers and reorganisations); the possibility to fire directors and managers at any time and without cause; and the absence of mandatory provisions on employee or state representatives on the board, which might weaken shareholder control.

The EXIT index includes legal rules that facilitate shareholders leaving the corporation. This includes a legal provision that protects the right to sell shares without prior approval by other shareholders or the company's directors (without exceptions to this rule, i.e. for bearer shares, which are often found in civil law countries); and the absence of extensive formal requirements for selling one's shares. EXIT also includes rules that facilitate exit by shareholders in case of take-overs and other major transactions, which may endanger their position in the company. In particular we include put options and mandatory take-over rules. In contrast to our VOICE index, there is no overlap with LLSVsh.

With ANTIMANAGE and ANTIBLOCK we assess the relative weight given by a legal system to the conflict between shareholders and management on the one hand, and minority shareholders and blockholders on the other. Comparative corporate governance analysis has shown that the conflict that is widely assumed to be at the heart of the governance problem, the principal-agent conflict between shareholders and managers, is not the relevant conflict in many countries (Berglöf 1995; Berglöf and von Thadden 1999; La Porta, Lopez-de-Silanes and Shleifer 1999). Firms with highly concentrated ownership typically have a shareholder with a stake large enough to effectively control management. The strong position of a blockholder may, however, endanger the position of minority shareholders. ANTIMANAGE includes legal rules aimed at protecting shareholders against management, such as the right of shareholders to challenge decisions taken by management in court, the right to fire management without cause, as well as rules against self-dealing by management personnel. Most of these indicators are included in LLSVsh. However, they also include some indicators, which protect shareholders not so much against management, 
but against dominant shareholders. To capture this difference, we created the index ANTIBLOCK. The right to challenge decisions taken by the shareholder meeting as opposed to decisions taken by the board is an example of shareholder rights included in ANTIBLOCK. Others are cumulative voting rights, pre-emptive rights of current shareholders in the case of new emissions, a quorum requirement of at least 50 percent for the shareholder meeting to take binding decisions, as well as put options for shareholders that have voted against major decisions affecting the current structure of the firm. Some of these indicators are also included in EXIT, others in LLSVsh.

Finally, we create a stock market integrity index (SMINTEGR). It codes rules, the primary purpose of which is not the protection of individual shareholder rights, but to ensure the integrity of the capital market. We use self-dealing and insider trading rules, provisions on the independence of a shareholder register, and the existence and formal independence of an agency charged with supervising the stock market to capture this function. While VOICE, EXIT, ANTIMANAGE and ANTIBLOCK are overlapping with the original LLSV index to a greater or lesser extent, SMINTEGR captures an entirely different aspect of legal protection, which may be of special relevance in transition. ${ }^{\text {B }}$

Legal change has been quite impressive along all six indices as can be seen from the change in indices between 1992 and 1998 shown in Table 1. Change across indices is difficult to measure, because the number of indicators used for each index varies. Yet, relative to the range of each index, VOICE clearly tops the list both in 1992 and in 1998. ANTIMANAGE comes out second and LLSVsh third, followed by EXIT. ANTIBLOCK and SMINTEGR take ranks five and six respectively. The fact that the ranking among indices does not change over time shows that law reform has affected shareholder rights across the board. There are, however, some variations once we break up transition economies by region. Incidentally, the three regions (Central/Eastern Europe \& Baltics, South-Eastern Europe, and CIS $)^{9}$ coincide with different legal traditions.

The CEE/Baltics, can trace their formal legal systems primarily to German law, and the countries of South-Eastern Europe to the Ottoman empire, which in turn was influenced by French law (David and Brierly 1985; Knapp 1972; Zweigert and Kötz 1984). In contrast, the countries of the CIS failed to develop a modern formal legal system prior to the revolution. The regional comparison shows that the countries of Central and Eastern Europe and the Baltics place greater emphasis on ANTIMANAGE and SMINTEGR than the other two regions. Yet, the most striking result of the regional comparison is that, contrary to expectation, at least with respect to shareholder rights, the law on the

\footnotetext{
${ }^{8}$ The Appendix shows the country scores for this index. Much has been made of the contrast between Czech and Polish securities market regulation. Our SMINTEGR index does not emphasise these differences, with scores of 3 and 4 as early as 1992 for the two countries. However, the one point difference may have been crucial in practice - it is due to the failure of the Czech republic to establish an independent securities commission that would have rigorously enforced existing regulations. As with any coding, the detailed experiences with legal reforms in each transition economy cannot be captured by our exercise.

${ }^{9}$ Country groups are as follows. CEE and the Baltics: Croatia, Czech Republic, Estonia, Hungary, Latvia, Lithuania, Poland, Slovak Republic, Slovenia. Southeastern Europe: Albania, Bosnia, Bulgaria, Romania, Macedonia. CIS: Armenia, Azerbaijan, Belarus, Georgia, Kazakhstan, Kyrgyzstan, Moldova, Russia, Ukraine, Uzbekistan.
} 
books in the countries of the former Soviet Union was not significantly less developed than in other transition economies even as early as 1992. This reflects the legal reforms that had taken place during the period of perestroika.

The scope of legal change in transition economies is also impressive on an international scale. The only index for which we have comparative data is the LLSV index. Table 2 compares the level of shareholder rights in transition economies in 1992 and 1998 with the world average and the average achieved by different legal families. Within a period of only six years, the average level of shareholder rights as measured by LLSVsh has improved from substantially below world average to well above world average. In fact, by 1998 the transition economies scored higher on this index than the three civil law families in the LLSV sample and are surpassed only by the common law countries. This seems to suggest a strong response by lawmakers to the problems of weak shareholder protection.

Shareholders are not the only providers of capital to a corporation. Indeed, Carlin and Mayer (1999) show that countries that are less economically developed and require capital intensive modernisation, may benefit more from debt financing. The quality of legal protection afforded to creditors in these countries would therefore be critical, as legal protection is likely to influence their willingness to lend. We use the index constructed by LLSV (LLSVcr) again as a starting point, but expand the list of indicators to thirteen, which allows us to construct three additional indices.

LLSVcr includes four variables, all of which address the role of creditors, and in particular secured creditors, in bankruptcy. The variables are as follows: (1) restrictions such as creditor consent exist for going into reorganisation as opposed to liquidation; (2) secured creditors are not stayed in bankruptcy, i.e. they can take out secured assets after bankruptcy proceedings have been opened; (3) secured assets are satisfied first when assets are distributed; and (4), management does not stay during bankruptcy, but is replaced with a court or creditor appointed manager/receiver. We expand the number of creditor rights variables and use them to construct additional indices. They allow us to distinguish between different types of creditor rights and also to measure a precondition for effective creditor rights - the existence of a well-developed collateral law. They are called CREDCON, REMEDY and COLLAT (see Appendix 1 for definitions).

CREDCON captures the extent to which creditors can control the bankruptcy process. It overlaps with LLSVcr, but excludes the first variable of that index. The reason is that in none of the countries in the sample is there a clear separation of liquidation and reorganisation procedures similar to the US model, which has clearly influenced the choice of this indicator. The index does, however, employ the other three variables of LLSVcr and adds two more variables: automatic trigger to go into bankruptcy, and creditor consent for adopting a liquidation or reorganisation plan. The difference to the variable on reorganisation vs. liquidation used by LLSV is the timing. While they focus on creditor consent at the time bankruptcy proceedings are initiated, we look at creditor consent during an ongoing bankruptcy proceeding. Not surprisingly, both indicators are highly correlated. 
The relevance of LLSVcr as well as CREDCON depends on the existence and scope of collateral rules in a legal system. The two indices assume that creditors can secure their claims and that information about security interests is readily available - an assumption that was not borne out by the facts in transition economies, especially not in the early days of reform. To capture the existence of legal provisions on security interests, we included the index COLLAT. We code whether land can be used as a collateral, security interests in moveable assets can be created without transferring the asset to the holder of the security interest, and whether the law includes provisions for a register to provide information about the existence of security interests in an asset that is in the possession of the debtor. Obviously, these indicators do not capture the range of security interests many legal systems offer, which include security interests not only in tangible assets, but also in present and future rights. They also do not include important functional substitutes, such as the transfer of full ownership title as a security in lieu of legal rules that would allow the creation of legally valid collateral without the creditor obtaining possession over the relevant asset. Yet, in transition economies an effective legal regime for security interests in tangible assets appears to be of primary importance.

The last index is called REMEDY. Creating a legal framework that allows them to secure their loans and to enforce their rights in an insolvency procedure can strengthen the position of creditors. These rules, which are captured in the CREDCON and COLLAT indices, give creditors ex ante control rights, which they can enforce in a bankruptcy procedure. Alternatively, or as a supplement to these rules, the law may allow creditors to impose sanctions on management ex post, which go beyond their original contractual rights or claims based on security interests. For instance, creditors may hold management liable for violating bankruptcy rules, or they may challenge the validity of transactions between the debtor and other parties that were carried out in the time immediately preceding bankruptcy. REMEDY addresses these ex post sanctions that are available both to secured and unsecured creditors, which could serve as functional substitutes for only weakly protected ex post rights. Neither REMEDY nor COLLAT overlaps with any of the other indices.

Table 3 compares the extent of change in these indices for the transition countries as a whole and across regions. Again, the extent of change between 1992 and 1998 is quite dramatic. In terms of the mean score of each index, LLSVcr ranks first in both years, followed by CREDCON, COLLAT, and finally, REMEDY. As with shareholder rights, the ranking of these indicators does not change over time indicating substantial reforms across the board rather than a more selective reform effort. In contrast to shareholder rights, however, the regional variation at the outset of reforms is more pronounced. The countries of Central and Eastern Europe and the Baltics have substantially more extensive creditor rights on the books as of 1992 than the two other regions. This has certainly put the least developed countries, which may have been in greatest need of capital intensive modernisation in a

\footnotetext{
${ }^{10}$ The situation in the countries of SEE is probably overstated, because we did not code the law in Yugoslavia, but include legal reform in Bosnia-Herzegovina, the FYR Macedonia, Croatia, and Slovenia since they enacted new laws.
} 
difficult starting position. However, the catch up in the other regions over time has been quite remarkable. Table 4 gives the scores for transition economies in comparison to other major legal families using the LLSVcr index. By 1998, these countries are well above the world average or the average score for any of the four legal families.

In summary, substantial efforts have been made to strengthen creditor and shareholder rights since the inception of economic reforms. Comparing the scope of change using six indices for shareholder rights and four for creditor rights, we find little evidence that law reform was conducted with a particular model of corporate governance in mind. Rather reform has proceeded on all fronts, and initial gaps - such as weak protection of creditors in the CIS were largely closed by 1998. One explanation for this across-the-board pattern of legal reform may be the process by which it was carried out. New laws were often drafted by foreign advisors and adopted by legislatures without major change. An example is the Russian corporate law, which transplanted a modified Anglo-American model of corporate law to this part of the world. European harmonisation guidelines have unleashed what some commentators have called a tornado of legislative activities in the countries wishing to join the EU. This approach to law reform gives the law receiving countries hardly a chance to read, much less to understand or adapt the legal concepts embodied in the new statutes to specific conditions of their countries. Without a proper understanding of the imported legal concepts, however, their role in influencing economic behaviour in the transition may be limited. Indeed, the next section shows that the scope of legal change we have documented in this section is not matched by similar improvements in the effectiveness of legal institutions.

\section{Law in action: The effectiveness of legal institutions}

The above analysis has focused exclusively on changes in the law on the books. These changes alone say little about the effectiveness of the new laws, i.e. their use in practice. This depends on the voluntary compliance rate on the one hand, and on the effectiveness of legal institutions that are charged with enforcing the law on the other. Both are mutually reinforcing. Where voluntary compliance is high, enforcement by the state is necessary in only a few cases and thus can be quite effective - provided that a minimum level of resources is available. Where compliance is low, however, the ability of enforcement institutions to ensure that the laws are used and followed in practice is rather limited to start with, and enhancing their effectiveness alone may not fundamentally alter the respect for the law. At the same time, voluntary compliance requires a credible threat that defection will be sanctioned. Effective law enforcement by the state may not be the exclusive, but is certainly an important element in making this threat viable.

We use three variables to measure the effectiveness of legal institutions in transition economies: (1) a rule of law rating provided by outside expert assessment; (2) an index of the effectiveness of corporate and bankruptcy law in transition economies constructed by the EBRD; and (3) survey data on the ability of the legal system to protect private property rights and enforce contracts, which we call the enforcement index. These variables are closely related, but not identical with indices that are commonly used in the literature to assess legal effectiveness. Following 
(Knack and Keefer 1995; Mauro 1995) and others, LLSV (1998) use for their 49 countries five indices: rule of law, the efficiency of the judiciary; the prevalence of corruption, contract repudiation and expropriation by the government. These data were not available to us for most of the transition economies.

For the rule of law rating, we use an expert assessment reported annually for 1996-1998 by the Central European Economic Review (CEER) ${ }^{1-2}$ The effectiveness index is taken from the EBRD Transition Reports, which uses survey data to rank countries according to the effectiveness of legal reforms in the area of corporate and bankruptcy law. Finally, the enforcement index is taken from the World Business Environment and Enterprise Performance (BEEPS) survey, implemented by EBRD in 20 transition economies during May-June 1999. It reports the percentage of firms in the sample that agree that the legal system will protect their property rights and enforce their contracts ${ }^{1}$ Table 5 reports the country scores and the correlation coefficients between these indicators.

All three measures of the effectiveness of legal institutions show striking differences among transition economies today. In fact, the variance in these measures is much larger than the variance in the law on the books as measured by the shareholder and creditor rights indices discussed in section 3 above. Using the BEEPS data on enforcement, for example, we find that the proportion of firms that do not trust the legal system to protect their rights, is staggering in many countries, particularly in the CIS. In Kyrgyzstan, Moldova, Russia and Ukraine, three quarters of all enterprises do not trust the legal system to enforce their rights. It is interesting to note the cases of Uzbekistan and Azerbaijan as outliers among the CIS - enterprises in both countries are relatively confident that their contract and property rights can be enforced in court. ${ }^{\text {. }}$

The broad pattern observable in the BEEPS is mirrored in our other legal effectiveness indices. While BosniaHerzegovina for obvious reasons ranks lowest on legal effectiveness in 1998, most other countries with low scores can be found in the former Soviet Union. The average for this region is 2.3, while the average in the Central and Eastern European countries is 3.1, and when dropping Bosnia-Herzegovina, even 3.4. The rule of law index shows similarly large cross-country variation. It ranges from a low of 1.4 in Tajikistan to a high of 8.7 in Hungary and Poland (on a scale of 1 to 10). The CIS average is 2.98 against an average in Central and Eastern Europe of 6.96. In spite of the similarity in the general pattern, the correlation coefficients between the enforcement index from the

\footnotetext{
${ }^{11}$ The "rule of law" index is based on several variables that measure the extent to which state power is transferred in an orderly manner, and law rather than violence is used for contract enforcement.

${ }^{12}$ This expert assessment comes closest to the ICRG rule of law ratings used by LLSV in their empirical work. Indeed, across the 20 transition economies for which a composite country risk index by ICRG is reported in the World Development Report 1999, the correlation with rule of law from CEER is 0.83 . We prefer the CEER rule of law rating since it captures the concept of effective legal institutions more directly than a composite risk index and is available for all the 24 countries for which we have legal indices as well.

${ }^{13}$ The enforcement index shows the average for each country uncorrected for size and industry. While the latter is not highly correlated with the perceived security of property and contract rights, size is. The results in the paper are not affected by the use of an enforcement index corrected for size effects.

${ }^{14}$ The results for Azerbaijan are partially driven by the above average size of companies surveyed in this country. Still, even correcting for size effects, both countries remain outliers.
} 
BEEPS survey and the two other legal effectiveness indices are not very high (below 0.4) - partially as a result of the two notable outliers in Azerbaijan and Uzbekistan. EBRD's effectiveness index and the rule of law rating are relatively highly correlated, with a coefficient of 0.64 for 1998. In the regressions of external finance against the indices of legal reform and legal effectiveness reported below, we tested all three indices.

The most striking aspect of the substantial variation in legal effectiveness across the region is that the high levels of formal legal protection achieved in many CIS countries by 1998 are not mirrored in similar improvements in the effectiveness of legal institutions. Indeed, we could not find a positive correlation between either the levels of formal legal protection on the books and legal effectiveness in 1998 or the change in formal laws in 1992-1998 and legal

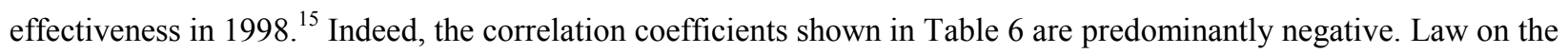
books does not correlate with legal effectiveness.

Unfortunately, our data on legal effectiveness does not extend back before 1996, so that the dynamic effects of legal reforms on changes in legal effectiveness cannot be properly investigated. Data for a limited number of countries (Albania, Bulgaria, Czechoslovakia, Hungary, Poland, Romania and the USSR) is available since the mid-1980s from the ICRG risk service. This shows that Bulgaria, Czechoslovakia, and Hungary traditionally had higher scores for rule of law than Albania, Romania and the USSR, suggesting a certain degree of persistence in these ratings. Moreover, the ratings for Russia declined dramatically immediately after independence in 1992 from a score of 4 (out of 10) to a score of 2, before making a gradual recovery after 1995. This limited evidence does suggest that improvements in the law on the books alone are certainly not sufficient to catalyze improvements in legal effectiveness.

The variance in legal effectiveness across countries and the fact that the quality of the law on the books has little or no explanatory power for the effectiveness of legal institutions requires further explanation. Berkowitz, Pistor and Richard (1999) argue that the demand for the law on the books, rather than its supply in the form of ready-made imported statutes may be crucial for explaining differences in legal effectiveness. Because law is a cognitive institution, legal rules on the books are not self-enforcing. Instead, they need to be applied by the endusers of the law or by legal intermediaries who understand their meaning and relevance for particular cases and existing socioeconomic conditions. This implies that the reception of foreign legal systems is likely to be more successful, if because of geographic proximity, a shared history, or immigration, the receiving endusers of the law are already familiar with the legal system. A similar result may be achieved by adapting the foreign law to local conditions. Thus, familiarity and adaptation are proxies for an active process of law reception.

A core proposition of Berkowitz et al. is that countries with familiarity and/or adaptation (receptive transplants) will have more effective legal institutions in the long run than those without similar predisposition (unreceptive

\footnotetext{
${ }^{15}$ Similar results were obtained by Berkowitz et al. (1999) for a data set of 49 countries put together by LLSV.
} 
transplants). Using the same data set as LLSV, their findings support this proposition. Where civil and commercial codes were in the past introduced into a legal system that was unfamiliar with them and failed to adapt the law to existing conditions, legal effectiveness today is significantly lower than in countries that developed these laws internally. Berkowitz et al. show that unreceptive transplants perform badly on all measures of the effectiveness of legal institutions - they thus suffer from the "transplant effect" 6 By contrast, where the legal transfer was smoothed by cultural proximity, legal adaptation and the availability of lawyers trained in the application of the new laws legal effectiveness today is very similar to countries that developed their formal legal systems internally (origins).

We adapt this approach to the transition economies in a very rudimentary form, and code transition economies for their familiarity with the type of laws that were then introduced. We do not look at the degree of adaptation in the post-socialist period primarily because we have no firm evidence on the extent of adaptation in legal reforms during the transition. Yet, the speed of legal changes and the extent to which these were driven by an agenda of rapid conversion to western standards suggest that room for local adaptation was limited throughout the region. This leaves the criterion of familiarity, which is largely historically determined.

For this purpose, we look back in history to the period when modern commercial laws were being introduced to the transition economies for the first time. Table 7 codes transition economies for the transplant effect. The coding in Table 7 relies on the period between the two world wars. Because many countries were formed only then, using earlier periods would require separate coding for different parts of what then became and today are the same country. For example, in 1918 Yugoslavia was governed by six different bodies of law, Romania and Poland by five, and Czechoslovakia by two. Many, but not all, of these countries, made serious efforts to overcome the multiplicity of legal regimes and enact unified codes, including civil and commercial codes. While only few countries succeeded by the time World War II broke out (Poland and Latvia; Korkisch 1958 and Schilling 1937), several others had developed drafts that were ready to be enacted. These drafts are considered for coding purposes. Countries that either succeeded in enacting a key laws, including a civil and commercial code, or which had a code ready to be enacted at the outbreak of World War II are coded as receptive transplants. Countries that did not accomplish major law reforms in that period are unreceptive transplants.

Not all countries in our sample can be coded as transplants. The countries that used to belong to the Soviet Union with the exception of the Baltic states - neither developed internally nor transplanted a formal modern legal order from the West prior to the advent of Socialism. Russia's attempt to enact a modern corporate law did not come to fruition before the revolution (Owen 1991) and it enacted its first civil code in 1924, that is after the establishment of the socialist system (David and Brierly 1985; Zweigert and Kötz 1984). Countries without previous exposure to the modern formal legal order before the collapse of the socialist system are called new transplants.

\footnotetext{
${ }^{16}$ Note that these results hold even when controlling for GDP per capita.
} 
How large is the impact of the history of legal reforms for the effectiveness of legal systems today? Table 8 presents average scores for legal effectiveness for the three groups of receptive, unreceptive and new transplants and t-tests for differences in means. The difference between receptive transplants and new transplants is pronounced and statistically significant. We have only 4 unreceptive transplants in the sample and their legal effectiveness scores are not statistically different from that of new transplants. However, legal effectiveness in unreceptive transplants is marginally lower than in receptive transplants, consistent with the evidence in Berkowitz et al. The results support our proposition that familiarity with transplanted laws and legal institutions greatly enhances the prospects for the effectiveness of legal institutions. Note that this result is not driven by differences in GDP per capita. In simple regressions of legal effectiveness against an ordinal transplant variable (scored 2 for receptive, 1 for unreceptive and 0 for new transplants) and GDP p.c. both are highly significant for the rule of law index. When either the EBRD's legal effectiveness or the BEEPS enforcement index are used GDP p.c. is insignificant.

In summary, rapid improvements in formal legal protection are not necessarily associated with improvements in law enforcement. Indeed, the extent and persistence of differences in legal effectiveness across the transition economies are indicative of the challenges faced by legal reformers during the transition. In this light, a strategy aiming to break out of the nexus of corporate governance problems through changes in formal laws alone may not work. The next section confirms that at least to date in the transition, legal effectiveness rather than the law on the books has had the predominant impact on external finance.

\section{Law and external finance in transition economies}

This section uses aggregate data on stock market capitalization and private sector credit to examine the impact of law on external finance, in the vein of the cross-country studies by LLSV and Levine (1998). At the country level, the ratio of stock market capitalization to GDP and of private sector debt (bank credit plus non-financial bonds) to GDP are the most commonly used indicators of external finance. For the transition economies, this raises a number of problems, which need to be borne in mind when interpreting the results that follow.

First, stock market capitalization may be influenced by forced listings in the context of a voucher privatization programme such as in the Czech Republic. Under these circumstances, indicators of market liquidity or the number of initial public offerings (IPOs) might be a better indicator of the depth and attractiveness of capital markets as a source of enterprise finance. To control for the impact of forced listings under voucher privatisation, we include a dummy variable in the regressions for all countries where equal access voucher privatisation was the main privatisation method.

\footnotetext{
${ }^{17} \mathrm{We}$ also experimented with the ratio of stock market turnover (value of shares traded per annum) to GDP as a dependent variable and find qualitatively the same results. The results are not shown for reasons of space but are
} 
Second, LLSV use a correction for market capitalisation to account only for those firms, where ownership is widely held. 18 This data was not available for the transition economies. Most observers of the region agree that the weaknesses in corporate governance have engendered a process of ownership consolidation, indeed in some cases a "scramble for control". Thus one would expect the correction for concentrated ownership to make quite a difference to market capitalisation in many transition economies. We believe that our central result that legal effectiveness is important in the transition would survive - it would be weakened only if ownership concentration varied systematically and positively with legal effectiveness. However, the reader should bear in mind the shortcomings of our data base in comparing our results with those obtained by LLSV.

Third, the stock of credit in several transition economies has been almost completely wiped out by the very high inflation rates at the beginning of the 1990s. Any analysis of the impact of the law on the depth of private credit markets thus has to take variations in the extent of initial inflation and the timing of stabilisation into account. We therefore include a measure of the number of years since the start of transition in which a country experienced stable macroeconomic conditions - taken to be inflation below $30 \%$ and a budget deficit below $5 \%$ of GDP.

Following LLSV, a number of additional factors may influence financial depth, for instance the size of the economy, its growth rate, and its level of income per capita. Our basic empirical model is written as:

$$
E F=\text { Const } .+\mathrm{a}^{*} \text { Law }+\mathrm{b}^{*} \text { LegalEff }+\mathrm{c}^{*} \text { Controls }+u,
$$

Where $E F$ is external finance, Law is represented by the indices for the law on the books of Section 3, LegalEff is represented by the indices for the effectiveness of legal institutions from Section 4, Controls comprises a vector of other exogenous variables (including the dummy for voucher privatisation, our measure of macro-stability and the other factors mentioned above) and $u$ is an error term, satisfying the normal properties. We ran a number of regressions with market capitalisation and private sector credit as the dependent variables. In order to correct for swings in stock prices between 1997 and 1998, we used the average capitalisation in these two years in all regressions.

Tables 9 and 10 report results for most of the indices of legal protection developed in Section 3 separately, to test whether some elements of the law may have been more important for the development of external finance than others. We do not report results for the ANTIMANAGE and CREDITCON indices as they are by construction very closely correlated with LLSV's original indices. We took the value of the legal indices achieved in 1998, assuming that law on the books affects the development of external finance directly without considerable lags. This may not be

available from the authors on request. The number of IPOs is available only for a limited number of countries - too few to conduct meaningful statistical analysis.

${ }^{18}$ The correction is one minus the average stake of the 10 largest corporations held by the 3 largest shareholders. 
realistic, as there may be learning effects that lead old laws to persist in their relevance for some time. However, law on the books if lagged has an increasingly negative impact on external finance the longer the lags, and this effect becomes significant for the 1992 value. This result partially reflects the extremely low starting values for shareholder and creditor rights in the former Yugoslav republics Slovenia and Croatia (see Appendix), which had among the most developed financial markets in 1998. It also reflects the relatively good starting position of the former Soviet Union at least with regard to shareholder protection. Given this counterintuitive result, a lag structure is no longer considered. Using contemporaneous scores for the legal indices to explain the level of external finance raises another problem, namely that current laws may have been in part influenced by financial market developments themselves. To get around this endogeneity problem, we used two-stage least squares with the lagged values of the legal indices as instruments for the current level of law on the books.

The three legal effectiveness indices from Section 4 were tested separately but in Tables 9 and 10 we report only the results using the rule of law index from the CEER. Legal effectiveness, as reported by EBRD, gives very similar results, while the results for the enforcement variable from the BEEPS survey are much weaker, albeit with similar signs. Again we used instrumental variable techniques with lags from earlier years (1995-1997) as instruments for legal effectiveness in 1998. The analysis of Section 4 suggests that a dummy variable for legal transplants might be a good alternative instrument. Indeed, all results are robust to using the "transplant" effect as an instrument for legal effectiveness.

A dummy for countries with equal access voucher privatisation (for the market capitalisation regressions) and a measure of macroeconomic stability (for the private credit regressions) were included as controls. We also tried using the log of GNP in US dollars and the average growth rate over the 1994-1998 period as controls, but as these were generally insignificant and used up scarce degrees of freedom, they were dropped. Following LLSV, we do not include GDP per capita as a control. It is highly correlated with our legal effectiveness variables and makes interpretation of standard errors difficult. All regressions were run using robust techniques to correct for heteroscedasticity.

Table 9 presents the main results for market capitalisation. They may be summarised as follows:

- Legal effectiveness has a positive impact on market capitalisation. This impact is quite large. Taking the OLS results, the difference between Russia's and Poland's rating for rule of law for instance would be sufficient to explain a 20 percentage point difference in market capitalisation (Table 9). To the extent that legal effectiveness is picking up the effect of more general development patterns (see note 19), the size of its coefficient cannot be

\footnotetext{
${ }^{19} \mathrm{We}$ did experiment with regressions using the residual of a simple regression of external finance against GDP p.c. and its squared value as the dependent variable. In all specifications, the legal variables of interest were not significant. Hence it is not clear, whether legal effectiveness has an impact on external finance independent of a general "level of development" factor. However, legal effectiveness may be an important factor in economic prosperity itself and hence the lack of an independent effect is not that surprising.
} 
interpreted too literally. However, our main interest here is to show the contrast to the indices for law on the books, which are all insignificant. This basic result is confirmed by the IV regressions.

- With respect to the separate indices of shareholder protection, the only one to achieve marginal significance is the SMINTEGR index, measuring the quality of securities markets regulations. In Table 9, SMIN98 has a positive coefficient, significant at the $10 \%$ level. This would seem to confirm the importance attributed to securities markets regulations by observers of the legal framework for corporate governance in transition economies (Coffee 1999b; Glaeser, Johnson and Shleifer 2000; Pistor 2000a). However, the value of the coefficient is small: a one point rise (corresponding to a $15 \%$ increase in the total range of the index, which ranges from 0 to 6 ) is associated with only a 1.5 percentage point increase in market capitalisation.

- The dummy for equal access voucher privatisation has a positive sign and is marginally significant in some of the regressions. However, the results are not particularly strong. Not all countries adopting equal access voucher privatisation had forced listings, explaining the weak results.

The results for private credit are shown in Table 10. The main results are:

- Again legal effectiveness tends to dominate the impact of the protection of creditor rights. And again the impact is quantitatively large. Following the OLS results, the difference in rule of law between Russia and Poland now would account for a 25 percentage point difference in private sector credit to GDP, although the same caveat on the possible effect of omitted GDP p.c. on the size of this coefficient applies. Creditor rights in 1998 are insignificantly related to private credit. This result holds for all three indices of legal protection developed in Section 3 and for both the OLS and IV specifications.

- The significance of legal effectiveness is greatly reduced if a measure for macroeconomic stability is included, measuring the proportion of years since the beginning of transition in which inflation was below $30 \%$ and the budget deficit below 5\%. Countries with macroeconomic instability tend to have lower private credit to GDP ratios, as bank claims are eroded by inflation. The regression coefficient suggests that one more year with macro-stability during the first decade of transition yields roughly a 3-4 percentage point increase in private sector credit to GDP. Macrostability is, however, highly correlated with the rule of law index, leading the latter to lose statistical significance when both are included. Multicollinearity was less of a problem with the effectiveness rating: both legal effectiveness and macrostability are significant (results not reported).

The regressions reported in Tables 9 and 10 are static. However, levels of external finance might be determined by some exogenous factors, such as starting points. Indeed, given that the transition economies are far away from a market economy equilibrium the level of external finance achieved in 1998 may still have mostly to do with the

\footnotetext{
${ }^{20}$ Slavova (1999) reports results, suggesting that the extensiveness of financial market regulations and company laws is more important than its effectiveness, where both extensiveness and effectiveness are taken from EBRD's survey of legal practitioners. The results are likely due to some degree of "blending" of the concepts of extensiveness and effectiveness inherent to the survey approach chosen by EBRD. The legal practitioners asked to rate the laws in the
} 
extent of the initial imbalance. This suggests trying an estimation in first differences to eliminate unaccounted level heterogeneity. A dynamic formulation moreover would allow one to test for the impact of changes in legal protection, controlling for initial levels. Data on private sector credit for a sufficient number of countries are available since 1994, so that the change in private credit between 1994 and 1998 can be used as the dependent variable. We test the following specification:

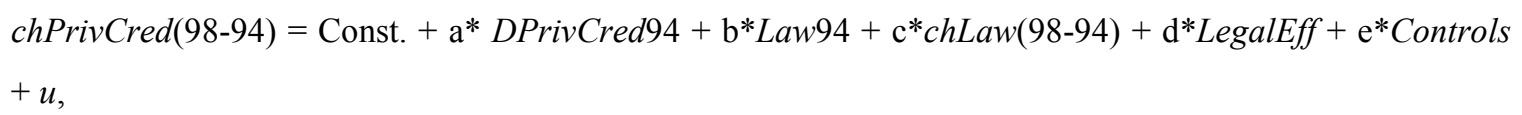

where PrivCred is the share of private credit in GDP, the prefix "ch" indicates change, the prefix "D" denotes the difference between private credit in GDP in 1994 and the level predicted by a market benchmark (determined by GDP per capita and its squared value), and all other variables are as defined above. Note that the specification assumes that legal effectiveness remains constant over the time period. As noted in Section 4, for the few countries where data is available over longer time periods, there does seem to be a certain persistence in country differences in legal effectiveness. Unfortunately, given the nature of the dependent variable, the use of lags as instruments for the legal indices is not as satisfactory. Changes in private sector credit over 1994-1998 may have had a feedback effect on legal reforms in each of these 5 years. Yet, the legal indices prior to 1994 are bad instruments for the level of law on the books achieved by 1998. Thus we report only OLS results, noting the possibility that the size of the coefficient on chLaw may be overestimated because of endogeneity to the growth in private credit.

The results, which appear in Table 11, are striking: once initial distortions are controlled for, creditor protection by the law seems to matter. Both the initial level in 1994 and the changes over 1994-1998 are positive and statistically significant, although the impact is not particularly large. A one-point increase in creditor protection during the 19941998 ( $25 \%$ of the total range) gives an increase of $5 \%$ of GDP in private sector credit. The results also show a clear tendency of adjustment towards the market benchmark with about half of the distance to the benchmark closed during this four-year period. Legal effectiveness as measured by the rule of law rating loses statistical significance in this dynamic specification. The EBRD's effectiveness rating produces a statistically significant coefficient, although its size is small: for every point increase in effectiveness (ranging from 1 to 4 ) private credit increases by around 5\% of GDP over this period. The macrostability measure is highly significant on its own, but loses significance when included jointly with legal effectiveness. The small size of the coefficients in the dynamic specification must be seen in the context of adjustment, where the coefficients express changes predicted over and above those that would naturally arise from convergence to the market benchmark. Indeed, when DprivCred 94 is excluded, the size of coefficients for Law on the books and legal effectiveness rises by around one-half.

country are reporting partially on their understanding of how these laws are applied - something which the coding approach chosen in this paper does not do. In this sense, Slavova's results may not be incompatible with ours. 
While we hesitate to draw strong conclusions from the results of the dynamic analysis, an exclusively pessimistic assessment of the role of legal reforms in transition does not seem warranted. If complemented with better law enforcement, the remarkable level of legal protection achieved in the transition economies may yet usher in a period of rapid growth in external finance. It is a matter of speculation whether the results also lend support to those emphasising the importance of developing credit markets during the transition. In the absence of longer time series on stock market capitalisation, this debate cannot be resolved with our data.

\section{Conclusion}

The most important lesson from this paper is that a key aspect of weak corporate governance in transition - namely the absence of external finance - cannot be solved only by even radical improvements in the legal framework for the protection of shareholder and creditor rights. The extent of legal reform in these areas of the law has been impressive by any standard. In fact, many of the countries of the former Soviet Union which received legal technical assistance primarily from the United States can today boast higher levels of investor rights protection on the books than some of the most developed market economies, such as France or Germany. Yet, it is unlikely that in the foreseeable future the development of the law will be matched by the development of financial markets.

An important constraint on financial market development is the absence of effective legal institutions. Our regression analysis shows that legal effectiveness has overall much higher explanatory power for the level of equity and credit market development than the quality of the law on the books. In their analysis of law and finance in 49 countries around the world, LLSV (1998) show that effective law enforcement is not a substitute for poor laws on the books. The experience of transition economies suggests that the reverse is also true: good laws cannot substitute for weak institutions.

History seems to be an important determinant for the effectiveness of legal institutions. More specifically, the low levels of legal effectiveness in much of the CIS seem to stem at least in part from the lack of legal modernisation in pre-Soviet Russia. Yet, as the contrast between receptive and unreceptive legal transplants among the transition economies (and developing countries) shows, legal reform strategies also matter. Indeed, a closer look at the law reform efforts in the inter-war period reveals that at the end of World War I most countries throughout Eastern and Southeastern Europe were confronted with initial conditions not too dissimilar to those of the transition economies today. They had been part of larger empires that had fallen apart; they had first been exposed to modern commercial and civil law while being part of these empires irrespective of whether these laws were a good fit for them or could be adapted to local conditions. In fact, several countries were governed by multiple legal orders. As a result, they were confronted with the task of building their own legal order. Those that lived up to this task laid the foundation for functioning legal institutions, which is still felt today. In contrast, those that failed to make a serious attempt at developing a modern legal order during this period do not distinguish themselves significantly from countries that had never been exposed to this type of law before. 
Given the small number of cases of unreceptive transplants among the transition economies, these conclusions should be treated with considerable caution. Clearly, the extent to which legal reforms are pro-active and adapted to local conditions may be a function of more general socio-economic conditions, such as the capacity of the state, which might also directly influence legal effectiveness. The apparent importance of familiarity and adaptation in supporting legal effectiveness might thus be spurious. Still, this paper cautions about legal reforms that transplant a new legal order wholesale from one country into another - often by stroke of a consultant's pen in the space of a few weeks. The law needs to be properly understood before it can be applied. Despite impressive achievements in formal legal change, many transition economies have yet to learn how to use their new legal order effectively. 

Table 1: Shareholder Rights Indices 1992 and 1998

\begin{tabular}{|c|c|c|c|c|c|c|c|c|}
\hline \multirow[b]{2}{*}{ Indicators* } & \multicolumn{4}{|c|}{1992} & \multicolumn{4}{|c|}{1998} \\
\hline & All & $\begin{array}{c}\text { CEE/ } \\
\text { Baltics }\end{array}$ & SEE & CIS & All & $\begin{array}{c}\text { CEE/ } \\
\text { Baltics }\end{array}$ & SEE & CIS \\
\hline $\begin{array}{l}\text { LLSVsh } \\
(0-6)\end{array}$ & 2.17 & 2 & 2 & 2.4 & 3.13 & 3.06 & 2.6 & 3.45 \\
\hline $\begin{array}{l}\text { VOICE } \\
(0-13)\end{array}$ & 5.89 & 4.69 & 4.85 & 7.4 & 7.86 & 6.72 & 6.7 & 9.5 \\
\hline $\begin{array}{l}\text { EXIT } \\
(0-4)\end{array}$ & 1.06 & 1.06 & 0.45 & 1.4 & 1.76 & 1.67 & 0.9 & 2.26 \\
\hline $\begin{array}{l}\text { ANTIMANAG } \\
\text { E } \\
(0-6)\end{array}$ & 2.58 & 2 & 2.8 & 2.3 & 3.6 & 3.33 & 3.6 & 3.85 \\
\hline $\begin{array}{l}\text { ANTIBLOCK } \\
(0-8)\end{array}$ & 1.85 & 1.72 & 2 & 1.9 & 3.49 & 3.53 & 3.3 & 3.55 \\
\hline $\begin{array}{l}\text { SMINTEGR } \\
(0-6)\end{array}$ & 0.96 & 1.44 & 0.6 & 0.7 & 2.86 & 3.44 & 2.4 & 2.58 \\
\hline
\end{tabular}

*The range of scores for each index is given in parentheses. Definitions of all indices are provided in the appendix.

Table 2 Shareholder Rights in Comparison

\begin{tabular}{lc}
\hline & Average of Shareholder Rights (LLSVsh) \\
\hline World Average (49 countries) & 3.0 \\
Common law family & 4.0 \\
French civil law family & 2.33 \\
German civil law family & 2.33 \\
Scandinavian civil law family & 3.0 \\
Transition economies 1992 & 2.17 \\
Transition economies 1998 & 3.13 \\
\hline
\end{tabular}

Source: La Porta et al. (1998) and compilation by authors.

Table 3: Creditor Rights Indices 1992 and 1998

\begin{tabular}{l|cccc|cccc}
\hline & \multicolumn{4}{|c|}{1992} & \multicolumn{4}{c}{1998} \\
\hline Indicators* & All & $\begin{array}{c}\text { CEE/ } \\
\text { Baltics }\end{array}$ & SEE & CIS & All & $\begin{array}{c}\text { CEE/ } \\
\text { Baltics }\end{array}$ & SEE & CIS \\
\hline $\begin{array}{l}\text { LLSVcr } \\
(0-4)\end{array}$ & 1.4 & 2.56 & 0 & 1.05 & 3.23 & 3.56 & 3 & 3.05 \\
$\begin{array}{l}\text { CREDCON } \\
(0-5)\end{array}$ & 1.65 & 3.11 & 0 & 1.15 & 3.69 & 4.33 & 3 & 3.45 \\
$\begin{array}{l}\text { COLLAT } \\
(0-3)\end{array}$ & 0.58 & 0.67 & 0.4 & 0.6 & 2.04 & 1.89 & 1.6 & 2.4 \\
$\begin{array}{l}\text { REMEDY } \\
(0-3)\end{array}$ & 0.42 & 0.83 & 0.2 & 0.15 & 1.38 & 1.25 & 1.35 & 1.5 \\
\hline
\end{tabular}

*The range of scores for each index is given in parentheses. Definitions of all indices are provided in the appendix.

Table 4 Creditor Rights in Comparison

\begin{tabular}{lc}
\hline & Average of Creditor Rights (LLSVcr) \\
\hline World Average (49 countries) & 2.30 \\
Common law family & 3.11 \\
French civil law family & 1.58 \\
German civil law family & 2.33 \\
Scandinavian civil law family & 2.0 \\
Transition economies 1992 & 1.40 \\
Transition economies 1998 & 3.23 \\
\hline
\end{tabular}

Source: La Porta et al. (1998) and compilation by authors. 
Table 5: Legal effectiveness in transition economies

\begin{tabular}{|c|c|c|c|c|}
\hline \multirow{2}{*}{ Country/Year } & \multirow{2}{*}{$\begin{array}{c}\text { Rule of Law (1) } \\
1998\end{array}$} & \multirow{2}{*}{$\frac{\text { Legal Effectiveness (2) }}{1998}$} & \multicolumn{2}{|c|}{ Enforcement (3) } \\
\hline & & & Now & 3 years ago \\
\hline Albania & 2.7 & 2 & NA & NA \\
\hline Armenia & 4.9 & 3 & 0.58 & 0.51 \\
\hline Azerbaijan & 3.2 & 2 & 0.73 & 0.66 \\
\hline Belarus & 2.3 & 2 & 0.46 & 0.48 \\
\hline Bosnia & 2.1 & 1 & NA & NA \\
\hline Bulgaria & 5.9 & 4 & 0.58 & 0.59 \\
\hline Croatia & 7 & 3 & 0.65 & 0.64 \\
\hline Czech Rep. & 8.3 & 4 & 0.45 & 0.44 \\
\hline Estonia & 8.5 & 4 & 0.77 & 0.61 \\
\hline FRY Macedonia & 5.4 & 4 & NA & NA \\
\hline Georgia & 4 & 3 & 0.62 & 0.39 \\
\hline Hungary & 8.7 & 4 & 0.71 & 0.76 \\
\hline Kazakhstan & 4.5 & 2 & 0.45 & 0.43 \\
\hline Kyrgyz Rep. & 4.4 & 2 & 0.30 & 0.35 \\
\hline Latvia & 7.5 & 2 & NA & NA \\
\hline Lithuania & 7.2 & 3 & 0.35 & 0.39 \\
\hline Moldova & 4.7 & 3 & 0.26 & 0.33 \\
\hline Poland & 8.7 & 4 & 0.75 & 0.70 \\
\hline Romania & 5.6 & 4 & 0.57 & 0.52 \\
\hline Russia & 3.7 & 2 & 0.27 & 0.25 \\
\hline Slovak Rep. & 6.4 & 2 & 0.64 & 0.59 \\
\hline Slovenia & 8.4 & 3 & 0.74 & 0.65 \\
\hline Tajikistan & 1.4 & 3 & NA & NA \\
\hline Turkmenistan & 2.5 & & NA & NA \\
\hline Ukraine & 3.4 & 2 & 0.26 & 0.30 \\
\hline Uzbekistan & 2.7 & 2 & 0.77 & 0.75 \\
\hline \multicolumn{2}{|c|}{$\begin{array}{l}\text { Correlation Rule of Law/Legal } \\
\text { Effectiveness }\end{array}$} & 0.64 & & \\
\hline \multicolumn{2}{|c|}{$\begin{array}{l}\text { Correlation Rule of } \\
\text { Law/Enforcement }\end{array}$} & 0.39 & & \\
\hline \multicolumn{2}{|c|}{$\begin{array}{l}\text { Correlation Enforcement/Legal } \\
\text { Effectiveness }\end{array}$} & 0.35 & & \\
\hline
\end{tabular}

1) Expert rating from a survey of regional experts in the Central European Economic Review. Ratings were published in 1996, 1997 and 1998.

2) Legal effectiveness rating from EBRD survey of legal practitioners across the region. Range from 1 to 4 (highest). The survey was administered each year since 1995. However, survey questions in 1995 and 1996 addressed investment laws rather than company laws. While similar effectiveness ratings were included in both earlier and later surveys, a fully consistent time series would have to be newly constructed from the raw data.

3) Proportion of firms in BEEPS survey who agree with the statement: "I am confident that the legal system will uphold any contract and property rights in business disputes".

Sources: Central European Economic Review, supplement to the Wall Street Journal; EBRD Transition Reports 1995-1998; World Business Environment and Enterprise Performance Survey (BEEPS). 
Table 6 - Law on the Books and Legal Effectiveness

Simple correlation coefficients

\begin{tabular}{|c|c|c|c|}
\hline Legal Index & Rule of Law & EBRD Effectiveness & BEEPS Enforcement \\
\hline LLSVsh 98 & -0.29 & -0.07 & -0.26 \\
\hline VOICE 98 & -0.39 & -0.27 & -0.37 \\
\hline ANTBLK 98 & -0.13 & 0.36 & -0.27 \\
\hline SMINTGR 98 & 0.15 & 0.34 & 0.10 \\
\hline EXIT 98 & -0.17 & -0.06 & -0.35 \\
\hline ANTIMG 98 & -0.09 & 0.04 & 0.09 \\
\hline LLSVcr 98 & 0.05 & -0.16 & 0.24 \\
\hline CREDCON 98 & $0.44^{*}$ & -0.05 & 0.36 \\
\hline COLLAT 98 & 0.04 & 0.25 & -0.04 \\
\hline REMEDY 98 & -0.12 & -0.33 & -0.02 \\
\hline "ChLLSVsh 92-98 & -0.31 & -0.12 & -0.27 \\
\hline ChVOICE 92-98 & -0.35 & -0.27 & -0.37 \\
\hline ChANTBLK 92-98 & -0.20 & 0.12 & -0.40 \\
\hline ChSMINTGR 92-98 & -0.06 & 0.14 & -0.00 \\
\hline ChEXIT 92-98 & 0.05 & -0.01 & -0.18 \\
\hline ChANTIMG 92-98 & 0.10 & 0.06 & 0.22 \\
\hline ChLLSVer 92-98 & -0.14 & -0.24 & 0.14 \\
\hline ChCREDCON 92-98 & -0.24 & -0.15 & 0.13 \\
\hline ChCOLLAT 92- 98 & -0.17 & 0.21 & 0.10 \\
\hline Ch REMEDY 92-98 & -0.21 & $-0.38^{*}$ & -0.18 \\
\hline
\end{tabular}

Note: A* means the correlation coefficient is statistically significant at the $10 \%$ level. Not all countries could be scored for all legal indices in 1992. The numbers of observations can thus differ from indicator to indicator, affecting the threshold level for statistical significance. 
Table 7 - Legal Transplants in Transition Economies

\begin{tabular}{|l|c|c|l|}
\hline Country & Adaptation & Familiarity & Type \\
\hline \hline Albania & 0 & 0 & Unreceptive \\
\hline Armenia & - & - & New transplant \\
\hline Azerbaijan & - & - & New transplant \\
\hline Belarus & - & 0 & New transplant \\
\hline Bosnia & 0 & 0 & Unreceptive \\
\hline Bulgaria & 1 & 1 & Receptive \\
\hline Croatia & 0 & 1 & Receptive \\
\hline Czech Rep & 1 & 1 & Receptive \\
\hline Estonia & 1 & 0 & Receptive \\
\hline FYR Macedonia & 0 & - & Unreceptive \\
\hline Georgia & - & 1 & New transplant \\
\hline Hungary & 1 & - & Receptive \\
\hline Kazakhstan & - & - & New transplant \\
\hline Kyrgyzstan & - & 1 & New transplant \\
\hline Latvia & 1 & 1 & Receptive \\
\hline Lithuania & 0 & - & Receptive \\
\hline Moldova & - & 0 & New transplant \\
\hline Poland & 1 & 0 & Receptive \\
\hline Romania & 1 & - & Receptive \\
\hline Russia & - & 0 & New transplant \\
\hline Slovak Rep & 0 & 1 & Unreceptive* \\
\hline Slovenia & - & - & Receptive \\
\hline Ukraine & - & New transplant \\
\hline Uzbekistan & - & New transplant \\
\hline & - & & \\
\hline
\end{tabular}

*Slovakia is a border-line case. Before the creation of Czechoslovakia, it was part of the Hungarian part of the Austro-Hungarian empire. Customary law governed private transactions. Czechoslovakia drafted a new civil and commercial code closely modeled on Austrian law. The first commission had no Slovak participants and they remained underrepresented.

Source: Compiled by authors. See text for details. 
Table 8 Legal Transplants and Legal Effectiveness

Average effectiveness scores for each country group

\begin{tabular}{|l|c|c|c|}
\hline Country Type & Rule of Law & Legal Effectiveness & Enforcement \\
\hline \hline Receptive transplants & 7.58 & 2.36 & 0.47 \\
\hline Unreceptive transplants & 4.15 & 2.25 & 0.64 \\
\hline New transplants & 3.48 & 3.50 & NA \\
\hline \hline $\begin{array}{l}\text { T-test } \\
\text { receptive/unreceptive }\end{array}$ & 0.019 & 0.069 & 0.006 \\
\hline $\begin{array}{l}\text { T-test receptive/new } \\
\text { T-test unreceptive/new }\end{array}$ & 0.000 & 0.000 & NA \\
\hline
\end{tabular}

Note: T-tests were conducted for differences in means. The table shows the probability of rejecting the null hypothesis of equal means. One-tailed t-tests were used.

The Rule of Law index ranges from 1-10 (high); legal effectiveness from 1-4 (high) and enforcement from 0-1

(high). For sources and definitions see Table 5. The enforcement variable was available only for the Slovak Republic among the unreceptive legal transplants and hence no t-test could be conducted. 
Table 9: Shareholder Rights and Capital Market Development

Dependent variable: Market Capitalisation / GDP, Ave. (97-98)

\begin{tabular}{|c|c|c|c|c|c|c|c|c|c|c|}
\hline & OLS & OLS & OLS & OLS & OLS & IV & IV & IV & IV & IV \\
\hline Variable & 1 & 2 & 3 & 4 & $\overline{5}$ & 1 & 2 & 3 & 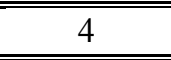 & $\overline{5}$ \\
\hline LLSVsh98 & $\begin{array}{c}0.9633 \\
(1.9562)\end{array}$ & . & & & & $\begin{array}{c}1.3011 \\
(2.9742)\end{array}$ & & & & \\
\hline VOICE98 & & $\begin{array}{c}0.5383 \\
(0.6752)\end{array}$ & & & & & $\begin{array}{c}0.3736 \\
(0.8093)\end{array}$ & & & \\
\hline SMIN98 & & & $\begin{array}{l}1.5511 * \\
(0.8692)\end{array}$ & & & & & $\begin{array}{c}1.2147 \\
(0.9573)\end{array}$ & & \\
\hline ANTBLK98 & & & & $\begin{array}{c}0.9260 \\
(1.0496)\end{array}$ & & & & & $\begin{array}{c}0.2214 \\
(1.4193)\end{array}$ & \\
\hline EXIT98 & & & & & $\begin{array}{c}0.3394 \\
(1.9274)\end{array}$ & & & & & $\begin{array}{c}1.1163 \\
(1.8590)\end{array}$ \\
\hline Rule of Law & $\begin{array}{c}3.6689 * * * \\
(1.1670)\end{array}$ & $\begin{array}{c}3.8944 * * * \\
(1.1391)\end{array}$ & $\begin{array}{c}3.4826^{* * * *} \\
(1.0390)\end{array}$ & $\begin{array}{c}3.5555 * * * \\
(2.1657)\end{array}$ & $\begin{array}{c}3.6711 * * * \\
(1.1637)\end{array}$ & $\begin{array}{c}3.5060 * * * \\
(1.1672)\end{array}$ & $\begin{array}{c}3.7742 * * * \\
(1.2614)\end{array}$ & $\begin{array}{c}3.6944 * * * \\
(0.9760)\end{array}$ & $\begin{array}{c}3.5100 * * * \\
(1.0892)\end{array}$ & $\begin{array}{c}3.6588 * * * \\
(1.0006)\end{array}$ \\
\hline Privatisation method & $\begin{array}{c}4.7138 \\
(3.8920)\end{array}$ & $\begin{array}{c}4.5985 \\
(3.9715)\end{array}$ & $\begin{array}{l}6.2178 * \\
(3.1082)\end{array}$ & $\begin{array}{c}4.9745 \\
(3.8956)\end{array}$ & $\begin{array}{c}5.1090 \\
(4.2474)\end{array}$ & $\begin{array}{c}4.1373 \\
(4.0586)\end{array}$ & $\begin{array}{c}4.7343 \\
(3.8105)\end{array}$ & $\begin{array}{l}6.3955^{*} \\
(3.1410)\end{array}$ & $\begin{array}{c}5.0167 \\
(3.8601)\end{array}$ & $\begin{array}{c}4.4270 \\
(3.7983)\end{array}$ \\
\hline R-Sq & 0.42 & 0.42 & 0.50 & 0.43 & 0.41 & 0.41 & 0.42 & 0.50 & 0.41 & 0.39 \\
\hline F-Statistic & $3.77 * *$ & $4.14 * *$ & $8.41 * * *$ & $4.98 * *$ & $5.05 * *$ & $3.47 * *$ & $3.10^{*}$ & $10.52 * * *$ & $5.36 * *$ & $5.47 * *$ \\
\hline Number of Observations & 19 & 19 & 19 & 19 & 19 & 19 & 19 & 19 & 19 & 19 \\
\hline
\end{tabular}

Note: Standard errors in parentheses; *** Significant at 1\%, ** Significant at 5\%, $*$ Significant at $10 \%$. Constants were included in regressions but are not reported. 
Table 10: Creditor Rights and Credit Market Development

Dependent variable: Private Credit / GDP, Ave. 97-98

\begin{tabular}{|c|c|c|c|c|c|c|c|c|c|c|}
\hline & OLS & OLS & OLS & OLS & OLS & IV & IV & IV & IV & IV \\
\hline Variable & 1 & 2 & 3 & 4 & 5 & 5 & 6 & 7 & 8 & 9 \\
\hline LLSVcr98 & $\begin{array}{c}0.8930 \\
(2.1943)\end{array}$ & $\begin{array}{l}-0.1795 \\
(1.9892)\end{array}$ & $\begin{array}{c}1.55 .15 \\
(2.0184)\end{array}$ & & & $\begin{array}{l}-0.1689 \\
(2.2768)\end{array}$ & $\begin{array}{l}-1.6259 \\
(1.8178)\end{array}$ & $\begin{array}{c}1.0885 \\
(2.1906)\end{array}$ & & \\
\hline REM98 & & & & $\begin{array}{c}1.3411 \\
(2.7223)\end{array}$ & & & & & $\begin{array}{c}0.6791 \\
(2.5776)\end{array}$ & \\
\hline COLAT98 & & & & & $\begin{array}{l}-6.9217 \\
(2.3143)\end{array}$ & & & & & $\begin{array}{c}-3.5862 \\
3.1645\end{array}$ \\
\hline Rule of Law & $\begin{array}{c}1.5729 \\
(1.8552)\end{array}$ & $\begin{array}{c}4.5143 * * * \\
(1.3955)\end{array}$ & & $\begin{array}{c}4.5647 * * * \\
(1.3869)\end{array}$ & $\begin{array}{c}2.0649 * * * \\
(0.9606)\end{array}$ & $\begin{array}{c}2.3742 \\
(1.7706)\end{array}$ & $\begin{array}{c}4.9719 * * * \\
(1.5221)\end{array}$ & & $\begin{array}{c}4.8352 * * * \\
(1.5526)\end{array}$ & $\begin{array}{l}2.0771 \\
1.4134\end{array}$ \\
\hline Macro-stability & $\begin{array}{l}33.6073 * \\
(17.4517) \\
\end{array}$ & & $\begin{array}{c}42.9166 * * * \\
(11.4697) \\
\end{array}$ & & $\begin{array}{c}28.7684 * * \\
(10.6477)\end{array}$ & $\begin{array}{l}28.9736^{*} \\
(16.2916) \\
\end{array}$ & & $\begin{array}{c}42.9863 * * * \\
(11.4461)\end{array}$ & & $\begin{array}{c}29.6737 * * \\
13.5834 \\
\end{array}$ \\
\hline R-Sq & 0.53 & 0.38 & 0.51 & 0.39 & 0.71 & 0.52 & 0.37 & 0.50 & 0.38 & 0.66 \\
\hline F-Statistic & $4.88 * *$ & $5.43 * * *$ & $7.02 * * *$ & $5.44 * *$ & $8.09 * * *$ & $4.92 * *$ & $5.34 * *$ & $7.06 * * *$ & $4.86^{* *}$ & $6.97 * *$ \\
\hline Number of Observations & 22 & 22 & 22 & 22 & 22 & 22 & 22 & 22 & 22 & 22 \\
\hline
\end{tabular}

Note: Standard errors in parentheses; *** Significant at $1 \%$, ** Significant at 5\%, $*$ Significant at $10 \%$

Constants were included in regressions but are not reported. 
Table 11: Initial creditor rights, legal change and credit markets Dependent variable: change in private credit / GDP 1994-1998

\begin{tabular}{|c|c|c|c|c|}
\hline & $\begin{array}{c}\text { Legal effectiveness } \\
\text { measure }=\text { rule of } \\
\text { law }\end{array}$ & & $\begin{array}{c}\text { Legal } \\
\text { effectiveness } \\
\text { measure }= \\
\text { effectiveness }\end{array}$ & \\
\hline Variable & 1 & 2 & 3 & 4 \\
\hline $\begin{array}{l}\text { Distance to } \\
\text { Benchmark } 1994\end{array}$ & $\begin{array}{l}-0.46^{* * * *} \\
(0.16)\end{array}$ & $\begin{array}{c}-0.54^{* * *} \\
(0.18)\end{array}$ & $\begin{array}{c}-0.43^{* * *} \\
(0.12)\end{array}$ & $\begin{array}{c}-0.47^{* * *} \\
(0.16)\end{array}$ \\
\hline LLSVcr.94 & $\begin{array}{l}3.20^{* *} \\
(1.49)\end{array}$ & $\begin{array}{c}3.06 \\
(1.82)\end{array}$ & $\begin{array}{l}3.01^{* *} \\
(1.36)\end{array}$ & $\begin{array}{l}2.78^{*} \\
(1.55)\end{array}$ \\
\hline ChLLSVer94-98 & $\begin{array}{l}5.32^{* * *} \\
(1.65)\end{array}$ & $\begin{array}{l}5.41^{* *} \\
(1.80)\end{array}$ & $\begin{array}{l}4.99^{* * *} \\
(1.41)\end{array}$ & $\begin{array}{c}4.94^{* * *} \\
(1.52)\end{array}$ \\
\hline $\begin{array}{l}\text { Legal effectiveness } \\
\text { (average 1996-1998) }\end{array}$ & $\begin{array}{l}1.25 \\
(0.74)\end{array}$ & - & $\begin{array}{l}4.82^{* *} \\
(1.76)\end{array}$ & $\begin{array}{l}4.00^{* *} \\
(1.78)\end{array}$ \\
\hline Macrostability & - & $\begin{array}{l}12.81 * \\
(7.21)\end{array}$ & - & $\begin{array}{c}4.78 \\
(7.30)\end{array}$ \\
\hline R-Sq. & 0.65 & 0.67 & 0.72 & 0.73 \\
\hline F-Statistic & $15.21^{* * *}$ & $15.01^{* * *}$ & $18.03^{* * *}$ & $12.98^{* * *}$ \\
\hline $\begin{array}{l}\text { Number of } \\
\text { Observations }\end{array}$ & 22 & 22 & 22 & 22 \\
\hline
\end{tabular}

Note: Standard errors in parentheses; ${ }^{*}$ Significant at $1 \%,{ }^{* *}$ Significant at $5 \%,{ }^{* * *}$ Significant at $10 \%$.

Constants were included in regressions but are not reported. 


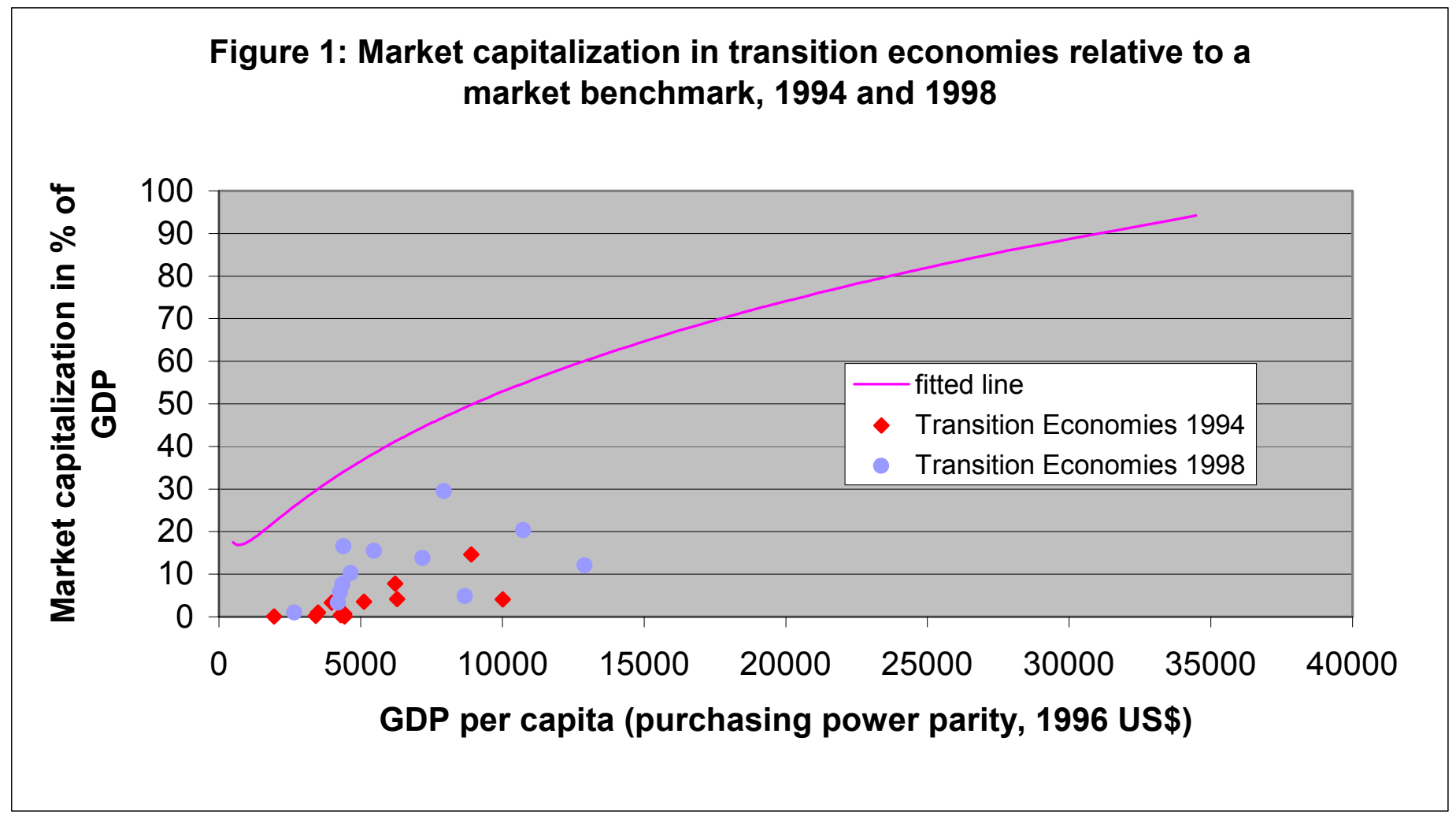

Note: The fitted line is estimated from a cross-country regression over 132 market economies of private credit/GDP against GDP per capita (in US dollars at purchasing power parities) and its squared value. The regression was run on data for 1996, obtained from the International Financial Statistics. See Transition Report 1998 for details. The data for the transition economies is reported in Appendix 4. 


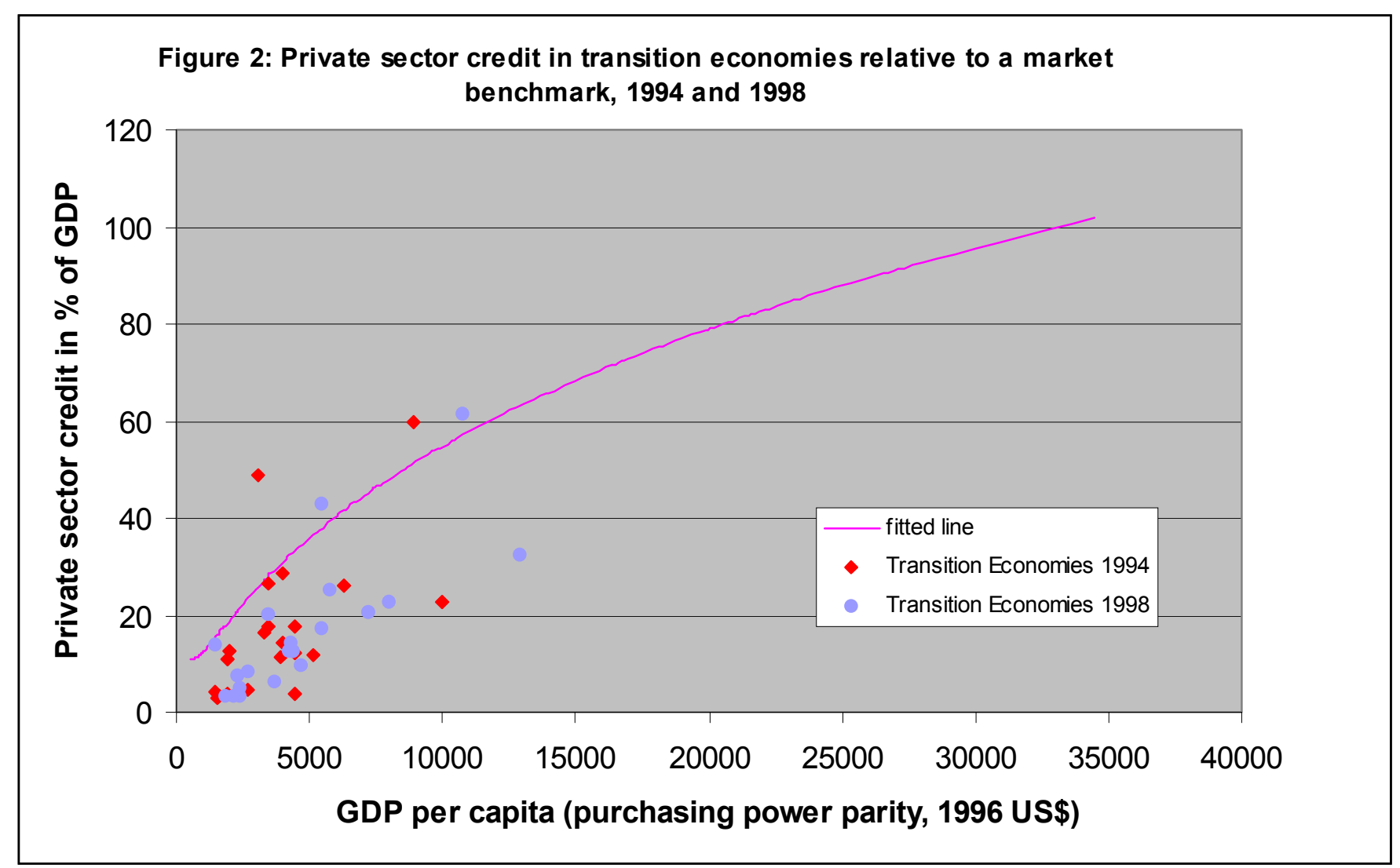

Note: The fitted line is estimated from a cross-country regression over 132 market economies of private credit/GDP against GDP per capita (in US dollars at purchasing power parities) and its squared value. The regression was run on data for 1996, obtained from the International Financial Statistics. See Transition Report 1998 for details. The data for the transition economies is reported in Appendix 4. 


\section{Appendix 1: Definition of shareholder and creditor rights indices}

Shareholder rights

\begin{tabular}{|c|c|c|c|c|c|c|}
\hline Indicator & LLSVsh* & VOICE & EXIT & $\begin{array}{c}\text { ANTI } \\
\text { MANAG }\end{array}$ & $\begin{array}{c}\text { ANTI } \\
\text { BLOCK }\end{array}$ & $\begin{array}{l}\text { SMIN } \\
\text { TEGR }\end{array}$ \\
\hline Mandatory One-Share-One Vote Rule & $(\mathrm{X})$ & & & & & \\
\hline Proxy by mail (not sufficient: authorisation of another person) & $\mathrm{X}$ & $\mathrm{X}$ & & & & \\
\hline Shares NOT blocked before the meeting & $\mathrm{X}$ & $\mathrm{X}$ & & & & \\
\hline No registration cut-off date before the meeting & $\mathrm{X}$ & $\mathrm{X}$ & & & & \\
\hline Cumulative voting for election of members of the board (supervisory board) & $\mathrm{X}$ & $\mathrm{X}$ & & & $\mathrm{X}$ & \\
\hline Other rules to ensure proportional board representation & $\mathrm{X}$ & $\mathrm{X}$ & & & $\mathrm{X}$ & \\
\hline Shareholder may take judicial recourse against decisions by executives, (supervisory) board & $\mathrm{X}$ & $\mathrm{X}$ & & $\mathrm{X}$ & & \\
\hline Shareholders may take judicial recourse against decisions taken by the shareholder meeting & $\mathrm{X}$ & $\mathrm{X}$ & & & $\mathrm{X}$ & \\
\hline Current shareholders have a pre-emptive right in case new shares are issued by company & $\mathrm{X}$ & $\mathrm{X}$ & & & $\mathrm{X}$ & \\
\hline $\begin{array}{l}\text { Shareholders, representing not more than } 10 \% \text { of total shares may demand convocation of } \\
\text { extraordinary shareholder meeting }\end{array}$ & $\mathrm{X}$ & $\mathrm{X}$ & & $\mathrm{X}$ & & \\
\hline $\begin{array}{l}\text { Audit commission may be called by minority shareholder representing not more than } 10 \% \text { of } \\
\text { shares }\end{array}$ & & $\mathrm{X}$ & & $\mathrm{X}$ & & \\
\hline Corporate statutes specify the amount of dividends to be paid out to shareholders & $(\mathrm{X})$ & & & & & \\
\hline $\begin{array}{l}\text { Executives (incl. general directors) are appointed/dismissed by the board (supervisory } \\
\text { board) rather than the shareholder meeting }\end{array}$ & & $\mathrm{X}$ & & $\mathrm{X}$ & & \\
\hline Members of the management/supervisory board may be dismissed at any time without cause & & $\mathrm{X}$ & & $\mathrm{X}$ & & \\
\hline $\begin{array}{l}\text { At least } 50 \% \text { of total voting shares must be represented at a SHM for it to take binding } \\
\text { decisions }\end{array}$ & & $\mathrm{X}$ & & & $\mathrm{X}$ & \\
\hline $\begin{array}{l}\text { Fundamental decisions, including charter changes, liquidation of companies, sale of major } \\
\text { assets, require qualified majority (at least } 3 / 4 \text { ) }\end{array}$ & & $\mathrm{X}$ & & & & \\
\hline $\begin{array}{l}\text { All (supervisory) board members are elected by shareholders (no mandatory representation } \\
\text { of employees or the public) }\end{array}$ & & $\mathrm{X}$ & & & & \\
\hline Right to Transfer shares is not restricted by law and may not be limited by charter & & & $\mathrm{X}$ & & & \\
\hline $\begin{array}{l}\text { Formal requirements for the transfer of shares are limited to endorsement (bearer shares) and } \\
\text { registration (registered shares) }\end{array}$ & & & $\mathrm{X}$ & & & \\
\hline $\begin{array}{l}\text { Minority shareholders have a put option (may demand that their shares are bought by the } \\
\text { company at fair value) in case they have voted against major transactions, including mergers, } \\
\text { reorganisation, sale of major assets, charter changes etc. }\end{array}$ & & & $\bar{X}$ & & $\bar{X}$ & \\
\hline Mandatory take over bid (threshold) & & & $\mathrm{X}$ & & $\mathrm{X}$ & \\
\hline $\begin{array}{l}\text { Rules against self-dealing, including rules on disclosing conflict of interest and abstaining } \\
\text { from voting are included in the law }\end{array}$ & & & & $\bar{X}$ & & $\bar{X}$ \\
\hline
\end{tabular}




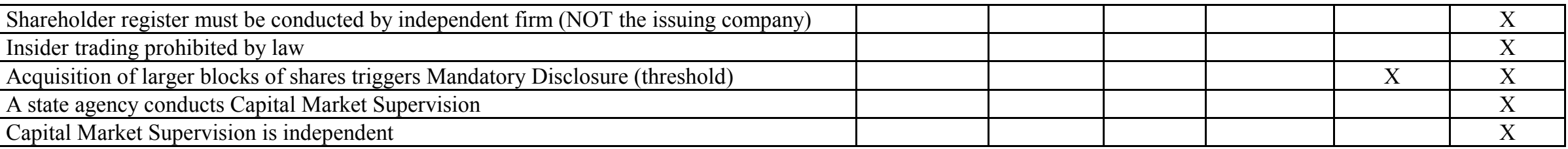

Capital Market Supervision is independent

Note: On the method for cumulating these indicators to yield our indices see the detailed explanation in Pistor (2000a). LLSV combine several of the above indicators

into one for their rating system. Those indicators originally coded by LLSV but not included in their cumulative index appear in parentheses.

\section{Creditor rights}

\begin{tabular}{|c|c|c|c|c|}
\hline Indicators & LLSVcr* & CREDCON & COLLAT & REMEDY \\
\hline \multicolumn{5}{|l|}{ Reorganisation procedure available } \\
\hline Restrictions for going into reorganisation (i.e. creditor consent) & $\mathrm{X}$ & & & \\
\hline No automatic stay on secured assets & $\mathrm{X}$ & $\mathrm{X}$ & & \\
\hline Secured assets first & $\mathrm{X}$ & $\mathrm{X}$ & & \\
\hline Management does not stay (receiver) & $\mathrm{X}$ & $\mathrm{X}$ & & \\
\hline $\begin{array}{l}\text { Legal reserve: } \\
\text { minimum percentage of total shares required to avoid voluntary dissolution }\end{array}$ & $(\mathrm{X})$ & & & \\
\hline Automatic trigger for filing & & $\mathrm{X}$ & & \\
\hline The adoption of a reorganisation or liquidation plan requires creditor consent & & $\mathrm{X}$ & & \\
\hline Management is liable, in case it violates provisions of insolvency law & & & & $\mathrm{X}$ \\
\hline Transactions preceding the opening of bankruptcy procedures may be declared null and void & & & & $\mathrm{X}$ \\
\hline Creditors may pierce the corporate veil & & & & $\mathrm{X}$ \\
\hline Establishing a Security Interest in movable assets does NOT require transfer of asset & & & $\mathrm{X}$ & \\
\hline Law requires establishment of register for security interests in movables & & & $\mathrm{X}$ & \\
\hline An (enforceable) security interest in land may be established & & & $\mathrm{X}$ & \\
\hline
\end{tabular}

Note: On the method for cumulating these indicators to yield our indices see the detailed explanation in Pistor (2000a). Those indicators originally coded by LLSV but not included in their cumulative index appear in parentheses. 
Appendix 2: Scores for Shareholder Rights Indices (1992-1998)

\begin{tabular}{|c|c|c|c|c|c|c|c|c|}
\hline \multirow[b]{2}{*}{ Country } & \multicolumn{4}{|c|}{ LLSVsh } & \multicolumn{4}{|c|}{ SMINTEGR } \\
\hline & 1992 & 1994 & 1996 & 1998 & 1992 & 1994 & 1996 & 1998 \\
\hline Albania & 3 & 3 & 3 & 3 & 1 & 1 & 1 & 1 \\
\hline Armenia & 2,5 & 2,5 & 5,5 & 5,5 & 0 & 3 & 5 & 5 \\
\hline Azerbaijan & 2,5 & 2 & 2 & 2 & 1 & 1 & 1 & 1 \\
\hline Belarus & 1,5 & 1,5 & 1,5 & 1,5 & 1 & 1 & 1 & 1 \\
\hline Bosnia & 0 & 0 & 0,5 & 0,5 & 0 & 0 & 0 & 0 \\
\hline Bulgaria & 4 & 4 & 4 & 4 & 1 & 1 & 5 & 5 \\
\hline Croatia & 0 & 2,5 & 2,5 & 2,5 & 0 & 1 & 6 & 6 \\
\hline Czech Rep & 2 & 2 & 3 & 3 & 3 & 3 & 4 & 5 \\
\hline Estonia & 2 & 2 & 3,75 & 3,75 & 0 & 2 & 4 & 4 \\
\hline FYR Macedonia & 0 & 0 & 2,5 & 2,5 & 0 & 0 & 1 & 5 \\
\hline Georgia & 2,5 & 2,5 & 3 & 3 & 0 & 0 & 0 & 0 \\
\hline Hungary & 2,5 & 2,5 & 2,5 & 3 & 3 & 3 & 3 & 5 \\
\hline Kazakhstan & 2,5 & 2,5 & 2,25 & 5,25 & 1 & 1 & 5 & 6 \\
\hline Kyrgyzstan & 2,5 & 2,5 & 2,25 & 2,25 & 0 & 0 & 2 & 2 \\
\hline Latvia & 3,5 & 3,5 & 3,5 & 3,5 & 1 & 1 & 1 & 1 \\
\hline Lithuania & 2,5 & 3,75 & 3,75 & 3,75 & 2 & 1 & 1 & 1 \\
\hline Moldova & 3 & 3 & 3 & 3,5 & 1 & 2 & 2 & 4,75 \\
\hline Poland & 3 & 3 & 3 & 3 & 4 & 4 & 4 & 4 \\
\hline Romania & 3 & 3 & 3 & 3 & 1 & 1 & 1 & 1 \\
\hline Russia & 2 & 2,5 & 5,5 & 5,5 & 2 & 3 & 3 & 3 \\
\hline Slovak Rep & 2,5 & 2,5 & 2,5 & 2,5 & 0 & 2 & 2 & 2 \\
\hline Slovenia & 0 & 2,5 & 2,5 & 2,5 & 0 & 3 & 3 & 3 \\
\hline Ukraine & 2,5 & 2,5 & 3 & 3,5 & 1 & 1 & 1 & 1 \\
\hline Uzbekistan & 2,5 & 2,5 & 3,5 & 3,5 & 0 & 0 & 2 & 2 \\
\hline
\end{tabular}




\begin{tabular}{lcccc|cccc}
\hline & \multicolumn{9}{c}{ VOICE } & \multicolumn{3}{c}{ EXIT } \\
\hline Albania & 1992 & 1994 & 1996 & 1998 & 1992 & 1994 & 1996 & 1998 \\
Armenia & 7,75 & 7,75 & 7,75 & 7,75 & 1 & 1 & 1 & 1 \\
Azerbaijan & 8 & 8 & 12 & 12 & 1 & 1 & 3 & 3 \\
Belarus & 8 & 7,5 & 7,5 & 7,5 & 1 & 1 & 1 & 1 \\
Bosnia & 6 & 6 & 6 & 6 & 1 & 1 & 1 & 1 \\
Bulgaria & 0 & 0 & 3,5 & 3,5 & 0 & 0 & 0 & 0 \\
Croatia & 10,75 & 10,75 & 10,75 & 10,75 & 0 & 0 & 2 & 2 \\
Czech Rep & 0 & 5,25 & 5,25 & 5,25 & 0 & 1 & 1 & 1 \\
Estonia & 3,5 & 3,5 & 4,5 & 4,5 & 1 & 1 & 2,5 & 2,5 \\
FYR Macedonia & 6,75 & 6,75 & 9,5 & 9,5 & 2 & 1 & 2 & 2 \\
Georgia & 0 & 0 & 5,75 & 5,75 & 0 & 0 & 0,5 & 0,5 \\
Hungary & 8 & 8 & 9 & 9 & 1 & 1 & 0 & 0 \\
Kazakhstan & 6,25 & 6,25 & 6,25 & 6,75 & 1,5 & 1,5 & 1,5 & 0,5 \\
Kyrgyzstan & 8 & 8 & 7,25 & 12,5 & 1 & 1 & 3 & 3 \\
Latvia & 7 & 7 & 9,25 & 9 & 1 & 1 & 2 & 2 \\
Lithuania & 7,25 & 7,25 & 7,25 & 7,25 & 1 & 1 & 1 & 1 \\
Moldova & 8,25 & 9,75 & 9,75 & 9,75 & 1 & 1 & 1 & 1 \\
Poland & 7,75 & 7,75 & 7,75 & 9 & 2 & 2 & 2 & 4 \\
Romania & 6,25 & 6,25 & 6,25 & 6,25 & 3 & 3 & 3 & 3 \\
Russia & 5,75 & 5,75 & 5,75 & 5,75 & 1 & 1 & 1 & 1 \\
Slovak Rep & 6 & 7 & 12 & 12 & 3 & 3 & 3,75 & 3,75 \\
Slovenia & 4 & 4 & 4 & 4 & 0 & 1 & 1 & 1 \\
Ukraine & 0 & 6,25 & 6,25 & 7,25 & 0 & 3 & 3 & 3 \\
Uzbekistan & 8 & 8 & 8 & 8,5 & 2 & 2 & 2 & 2 \\
\hline
\end{tabular}




\begin{tabular}{lcccc|cccc}
\hline & \multicolumn{9}{c}{ ANTIMANAG } & \multicolumn{5}{c}{ ANTIBLOCK } \\
\hline & 1992 & 1994 & 1996 & 1998 & 1992 & 1994 & 1996 & 1998 \\
Albania & 5 & 5 & 5 & 5 & 3 & 3 & 3 & 3 \\
Armenia & 2,5 & 2,5 & 5 & 5 & 2 & 2 & 4,5 & 4,5 \\
Azerbaijan & 2,5 & 3 & 3 & 3 & 2 & 1 & 1 & 1 \\
Belarus & 1,5 & 1,5 & 1,5 & 1,5 & 1 & 1 & 1 & 1 \\
Bosnia & 0 & 0 & 1,5 & 1,5 & 0 & 0 & 0 & 0 \\
Bulgaria & 5 & 5 & 5 & 5 & 3 & 3 & 5 & 5 \\
Croatia & 0 & 4 & 4 & 4 & 0 & 2 & 3 & 3 \\
Czech Rep & 2 & 2 & 2 & 2 & 1 & 1 & 4,5 & 4,5 \\
Estonia & 2 & 2 & 4,5 & 4,5 & 1 & 1 & 4 & 4 \\
FYR Macedonia & 0 & 0 & 2,5 & 2,5 & 0 & 0 & 3,5 & 4,5 \\
Georgia & 2,5 & 2,5 & 4 & 4 & 2 & 2 & 2 & 2 \\
Hungary & 2 & 2 & 2 & 4 & 2,5 & 2,5 & 2,5 & 4,5 \\
Kazakhstan & 2,5 & 2,5 & 3,5 & 5,5 & 2 & 2 & 3 & 6,25 \\
Kyrgyzstan & 1,5 & 1,5 & 3,5 & 4 & 2 & 2 & 3 & 3 \\
Latvia & 3 & 3 & 3 & 3 & 3 & 3 & 3 & 3 \\
Lithuania & 4 & 3,5 & 3,5 & 3,5 & 2,5 & 3,5 & 3,5 & 3,5 \\
Moldova & 2 & 2 & 2 & 3 & 2 & 2 & 2 & 6,25 \\
Poland & 3 & 3 & 3 & 3 & 4,5 & 4,5 & 4,5 & 4,5 \\
Romania & 4 & 4 & 4 & 4 & 4 & 4 & 4 & 4 \\
Russia & 3 & 3 & 5 & 5 & 2 & 2,5 & 6 & 6 \\
Slovak Rep & 2 & 2 & 2 & 2 & 1 & 1 & 1 & 1 \\
Slovenia & 0 & 3 & 3 & 4 & 0 & 3,75 & 3,75 & 3,75 \\
Ukraine & 2,5 & 2,5 & 2,5 & 3 & 2 & 2 & 2 & 2 \\
Uzbekistan & 2,5 & 2,5 & 5 & 5 & 2 & 2 & 3,5 & 3,5 \\
\hline
\end{tabular}


Appendix 3: Scores for Creditor Rights Indices (1992-1998)

\begin{tabular}{lcccc|cccc}
\hline & \multicolumn{3}{c}{ LLSVcr } & \multicolumn{5}{c}{ CREDCON } \\
\hline Country & 1992 & 1994 & 1996 & 1998 & 1992 & 1994 & 1996 & 1998 \\
Albania & 0 & 0 & 3 & 3 & 0 & 3 & 3 & 3 \\
Armenia & 0 & 0 & 0 & 3 & 0 & 0 & 0 & 4 \\
Azerbaijan & 0 & 3 & 3 & 4 & 0 & 4 & 4 & 3 \\
Belarus & 2 & 2 & 2 & 2 & 3 & 3 & 3 & 3 \\
Bosnia & 0 & 0 & 0 & 4 & 0 & 0 & 0 & 4 \\
Bulgaria & 0 & 3 & 3 & 3 & 0 & 4 & 4 & 4 \\
Croatia & 0 & 0 & 4 & 4 & 0 & 0 & 5 & 5 \\
Czech Rep & 3 & 3 & 3 & 3 & 4 & 4 & 4 & 4 \\
Estonia & 3 & 3 & 3 & 4 & 4 & 4 & 4 & 4 \\
FYR Macedonia & 0 & 0 & 1 & 1 & 0 & 0 & 0 & 0 \\
Georgia & 0 & 0 & 2,75 & 2,75 & 0 & 0 & 2,75 & 2,75 \\
Hungary & 3,75 & 3,75 & 3,75 & 3,75 & 4,75 & 4,75 & 4,75 & 3,75 \\
Kazakhstan & 1,5 & 1,5 & 1,5 & 2,75 & 1,5 & 1,5 & 1,5 & 2,75 \\
Kyrgyzstan & 0 & 0 & 0 & 3 & 0 & 0 & 0 & 3 \\
Latvia & 4 & 4 & 4 & 4 & 4 & 4 & 5 & 5 \\
Lithuania & 4 & 4 & 4 & 3 & 3 & 3 & 3 & 3 \\
Moldova & 3 & 3 & 3 & 4 & 3 & 3 & 3 & 4 \\
Poland & 2,25 & 2,25 & 2,25 & 2,25 & 4,25 & 4,25 & 4,25 & 4,25 \\
Romania & 0 & 0 & 4 & 4 & 0 & 0 & 4 & 4 \\
Russia & 0 & 3 & 3 & 2,5 & 0 & 3 & 3 & 3,5 \\
Slovak Rep & 3 & 3 & 3 & 4 & 4 & 4 & 4 & 5 \\
Slovenia & 0 & 4 & 4 & 4 & 0 & 5 & 5 & 5 \\
Ukraine & 4 & 4 & 4 & 4 & 4 & 4 & 4,5 & 4 \\
Uzbekistan & 0 & 2,5 & 2,5 & 2,5 & 0 & 4,5 & 4,5 & 4,5 \\
& & & & & & & \\
\end{tabular}




\begin{tabular}{lcccc|cccc}
\hline & \multicolumn{1}{c}{ COLLAT } & \multicolumn{5}{c}{ REMEDY } \\
\hline Country & 1992 & 1994 & 1996 & 1998 & 1992 & 1994 & 1996 & 1998 \\
Albania & 0 & 1 & 1 & 1 & 1 & 1 & 2 & 2 \\
Armenia & 0 & 0 & 2 & 2 & 0 & 0 & 0 & 1 \\
Azerbaijan & 0 & 0 & 1 & 3 & 0 & 0,5 & 0,5 & 1,75 \\
Belarus & 1 & 1 & 1 & 1 & 0,75 & 0,75 & 0,75 & 0,75 \\
Bosnia & 0 & 0 & 0 & 0 & 0 & 0 & 0 & 0,75 \\
Bulgaria & 1 & 1 & 3 & 3 & 0 & 2 & 2 & 2 \\
Croatia & 0 & 0 & 1 & 1 & 0 & 0 & 2 & 2 \\
Czech Rep & 1 & 1 & 1 & 1 & 1 & 1 & 1 & 1 \\
Estonia & 0 & 3 & 3 & 3 & 1 & 1 & 1 & 1 \\
FYR Macedonia & 1 & 1 & 1 & 3 & 0 & 0 & 0 & 0 \\
Georgia & 0 & 2 & 2 & 3 & 0 & 0 & 0 & 0 \\
Hungary & 1 & 1 & 3 & 3 & 1 & 1 & 1 & 1 \\
Kazakhstan & 2 & 2 & 2 & 3 & 0 & 0 & 1 & 2,75 \\
Kyrgyzstan & 0 & 0 & 1 & 3 & 0 & 0 & 0 & 2,75 \\
Latvia & 0 & 0 & 0 & 1 & 0,75 & 0,75 & 0,75 & 1 \\
Lithuania & 1 & 1 & 1 & 3 & 0,75 & 0,75 & 0,75 & 0 \\
Moldova & 0 & 1 & 2 & 3 & 0 & 0 & 1 & 1 \\
Poland & 1 & 1 & 1 & 3 & 1,5 & 1,5 & 1,5 & 1,5 \\
Romania & 0 & 0 & 0 & 1 & 0 & 0 & 2 & 2 \\
Russia & 1 & 1 & 1 & 2 & 0 & 0,5 & 1,5 & 2,5 \\
Slovak Rep & 1 & 1 & 1 & 1 & 1,5 & 1,5 & 1,5 & 2 \\
Slovenia & 1 & 1 & 1 & 1 & 0 & 1,75 & 1,75 & 1,75 \\
Ukraine & 2 & 2 & 2 & 2 & 0,75 & 0,75 & 0,75 & 0,75 \\
Uzbekistan & 0 & 0 & 0 & 2 & 0 & 1,75 & 1,75 & 1,75 \\
\hline
\end{tabular}


Appendix 4 - Stock Market Capitalisation, Private Credit, and Stock Market Turnover in Transition Economies, in per cent of GDP

\begin{tabular}{|c|c|c|c|c|c|}
\hline Country & $\begin{array}{l}\text { Market } \\
\text { Capitalisation/GDP } \\
1994\end{array}$ & $\begin{array}{l}\text { Market } \\
\text { Capitalisation/ } \\
\text { GDP } 1998 \\
\end{array}$ & $\begin{array}{l}\text { Private } \\
\text { Credit/GDP } 1994\end{array}$ & $\begin{array}{l}\text { Private } \\
\text { Credit/GDP } \\
1998\end{array}$ & $\begin{array}{l}\text { Stock Market } \\
\text { Turnover/GDP } \\
1998\end{array}$ \\
\hline Albania & NA & NA & 3.83 & 3.33 & NA \\
\hline Armenia & 0.10 & 0.97 & 11.08 & 8.57 & $0.00 *$ \\
\hline Azerbaijan & NA & 0.08 & 3.33 & 3.33 & 0.00 \\
\hline Belarus & $\mathrm{NA}$ & NA & 17.59 & 17.11 & NA \\
\hline Bulgaria & 0.66 & 7.65 & 3.76 & 12.66 & 0.00 \\
\hline Croatia & 3.31 & 15.46 & 28.56 & 43.06 & 0.51 \\
\hline Czech Republic & 14.64 & 20.36 & 59.77 & 61.62 & 8.60 \\
\hline Estonia & $\mathrm{NA}$ & 9.46 & 14.11 & 25.30 & 18.02 \\
\hline FYR Macedonia & $\mathrm{NA}$ & 0.25 & 48.81 & 20.10 & 0.00 \\
\hline Georgia & $\mathrm{NA}$ & NA & 4.03 & 3.48 & $\mathrm{NA}$ \\
\hline Hungary & 4.16 & 29.49 & 26.21 & 22.80 & 33.79 \\
\hline Kazakhstan & $\mathrm{NA}$ & 7.99 & 26.57 & 6.43 & 0.14 \\
\hline Kyrgyzstan & $\mathrm{NA}$ & NA & 12.54 & 5.12 & 0.01 \\
\hline Latvia & 0.23 & 5.78 & 16.43 & 14.13 & 1.34 \\
\hline Lithuania & 0.98 & 10.21 & 17.63 & 9.66 & 2.12 \\
\hline Moldova & NA & 4.56 & 3.02 & 13.88 & 4.43 \\
\hline Poland & 3.54 & 13.77 & 11.97 & 20.76 & 5.97 \\
\hline Romania & 0.36 & 3.29 & 11.33 & 12.75 & 1.59 \\
\hline Russia & 0.08 & 16.54 & 12.13 & 12.66 & 2.55 \\
\hline Slovakia & 7.76 & 4.88 & 24.34 & 44.21 & 5.10 \\
\hline Slovenia & 4.08 & 12.12 & 22.53 & 32.40 & 3.57 \\
\hline Ukraine & NA & 1.87 & 4.62 & 7.51 & 0.20 \\
\hline
\end{tabular}

Source: International Financial Statistics, IFC Emerging Markets Handbook.

* Data for Armenia are from 1996. In all regressions of market capitalisation and turnover, the average of data for 1997 and 1998 is used. 
References:

Bebchuk, Lucian. 1989. Limiting Contractual Freedom in Corporate Law: The Desirable Constraints on Charter Amendments. Harvard Law Review 102:1820-1860.

Berglöf, Erik. 1995. Corporate Governance in Transition Economies: The Theory and Its Policy Implications. In Corporate Governance in Transitional Economies, edited by M. Aoki and H.-K. Kim. Washington, D.C.: The World Bank: 59-98.

Berglöf, Erik, and Ernst-Ludwig von Thadden. 1999. The Changing Corporate Governance Paradigm: Implications for Transition and Developing Countries. In Proceedings of the Annual Bank Conference on Development Economics. Washington, D.C.: The World Bank (forthcoming).

Berkowitz, Daniel, Katharina Pistor, and Jean-Francois Richard. 1999. Economic Development, Legality, and the Transplant Effect. mimeo, Harvard University.

Black, Bernard, Reinier Kraakman, and Anna Tarassova. 1999. Russian Privatization and Corporate Governance: What Went Wrong? Stanford: Working Paper John M. Olin Program in Law and Economics.

Black, Bernard S. 1990. Is Corporate Law Trivial?: A Political and Economic Analysis. Northwestern University Law Review 84:542-597.

Calvo, G., and F. Coricelli. 1992. Stagflationary Effects of Stabilisation Programmes in Reforming Socialist Economies: Enterprise-side versus Household-side Factors. World Development Review 6 (1):71-90.

Carlin, Wendy, and Colin Mayer. 1999. Finance, Investment and Growth.CEPR Discussion Paper No. 2233.

Coffee, John C., Jr. 1989. The Mandatory/Enabling Balance in Corporate Law: An Essay on the Judicial Role. Columbia Law Review 89:1618-1691.

Coffee, John C., Jr. 1991. Liquidity Versus Control: The Institutional Investor as Corporate Monitor. Columbia Law Review 91:1277-1368.

Coffee, John C. Jr. 1998. Inventing a Corporate Monitor for Transitional Economies: The Uncertain Lessons from the Czech and Polish Experiences. In Comparative Corporate Governance - The State of the Art and Emerging Research, edited by K. J. Hopt, H. Kanda, M. J. Roe, E. Wymeersch and S. Prigge. Oxford: Clarendon Press: 67-138.

Coffee, John C. Jr. 1999a. The Future As History: The Prospects for Global Convergence in Corporate Governance and Its Implications. Northwestern University Law Review 93 (2):631-707.

Coffee, John C. Jr. 1999b. The Lessons From Securities Market Failure: Privatization, Minority Protection, and Investor Confidence. Draft, September 1999.

Coffee, Jack C. Jr. 1999c. Privatization and Corporate Governance: The Lessons from Securities Market Failure. Journal of Corporation Law 25:1-39.

David, Rene, and John E. Brierly. 1985. Major Legal Systems in the Word Today. London: Steven \& Sons.

Demirguc-Kunt, Asli, and Vojislav Maksimovic. 1998. Law, Finance and Firm Growth. Journal of Finance 53 (6):2107-2137.

Easterbrook, Frank H., and Daniel R. Fischel. 1991. The Economic Structure of Corporate Law. Cambridge, Mass.: Harvard University Press.

EBRD. 1997. Transition Report - Enterprise Performance and Growth. London: European Bank for Reconstruction and Development.

EBRD. 1998. Transition Report - Financial Sector in Transition. London: European Bank for Reconstruction and Development.

EBRD. 1999. Transition report - Ten Years of Transition. London: European Bank for Reconstruction and Development.

Frydman, Roman, Katharina Pistor, and Andrzej Rapaczynski. 1996. Investing in Insider-Dominated Firms: A Study of Russian Voucher Privatization Funds. In Corporate Governance in Central Europe and Russia, edited by R. Frydman, C. W. Gray and A. Rapaczynski. Budapest, London, New York: CEU Press: 187-241.

Glaeser, Edward, Simon Johnson, and Andrei Shleifer. 2000. Coas vs. Coasians, mimeo Harvard University.

Hirschman, Albert O. 1970. Exit, Voice, and Loyalty; Responses to Decline in Firms, Organizations, and States. Cambridge, MA: Harvard University Press

Knack, Stephen, and Philip Keefer. 1995. Institutions and Economic Performance: Cross-Country Tests Using Alternative Institutional Measures. Economics and Politics 7: 207-227.

Knapp, Viktor, ed. 1972. National Reports (various issues). In International Encyclopedia of Comparative Law, edited by Rene David et al. Tübingen: J.C.B. Mohr. 
Korkisch, Friedrich. 1958. Das Privatrecht Ost-Mitteleuropas in rechsvergleichender Sicht (The Private Law of EastCentral Europe in Comparative Analysis). Rabels Zeitschrift 23:201-230.

Kornai, Janos. 1992. The Socialist System: The Political Economy of Communism. Princeton, N.J.: Princeton University Press.

La Porta, Rafael, Florencio Lopez-de-Silanes, and Andrei Shleifer. 1999. Corporate Ownership Around the World. Journal of Finance LIV (2):471-517.

La Porta, Rafael, Florencio Lopez-de-Silanes, Andrei Shleifer, and Robert W. Vishny. 1997. Legal Determinants of External Finance. Journal of Finance LII (3):1131-1150.

La Porta, Rafael, Florencio Lopez-de-Silanes, Andrei Shleifer, and Robert W. Vishny. 1998. Law and Finance. Journal of Political Economy 106 (6):1113-1155.

Levine, Robert. 1997. Law, Finance, and Economic Growth. mimeo University of Virginia, Department of Economics, University of Virginia.

Levine, Ross. 1998. The Legal Environment, Banks, and Long-Run Economic Growth. Journal of Money, Credit, and Banking 30 (3):596-613.

Levine, Ross, and Sara Zervos. 1996. Stock Markets, Banks, and Economic Growth. Working Paper, Washington D.C.: The World Bank.

Mauro, Paolo. 1995. Corruption and Growth. The Quartely Journal of Economics CX (3):681-712.

Owen, Thomas C. 1991. The Corporation under Russian Law, 1800-1917. Cambridge, UK: Cambridge University Press.

Pistor, Katharina. 2000a. Law as a Determinant for Stockmarket Development in Eastern Europe. In Assessing the Value of Law in Transition Economies, edited by P. Murrell. Ann Arbor: University of Michigan Press.

Pistor, Katharina. 2000b. Patterns of Legal Change: Shareholder and Creditor Rights in Transition Economies. European Business Organization Law Review 1 (1): (forthcoming).

Pistor, Katharina , and Philip Wellons. 1999. The Role of Law and Legal Institutions in Asian Economic Development. Hong Kong: Oxford University Press.

Rajan, Raghuram G., and Luigi Zingales. 1998. Financial Dependence and Growth. American Economic Review 88: 559-586.

Schilling, von. 1937. Lettlands neues Zivilgesetzbuch (Latvia's new Civil Code). Rabels Zeitschrift 11:484-519.

Shleifer, Andrei, and Robert W. Vishny. 1997. A Survey of Corporate Governance. The Journal of Finance LII (2):737-783.

Stiglitz, Joseph. 1999. Quis Custodiet Ipsos Custodes? Paper presented at the Annual Bank Conference on Development Econmics - Europe, Paris: June.

Trubek, David M., and Marc Galanter. 1974. Scholars in Self-Estrangement: Some Reflections on the Crisis in Law and Development Studies in the United States. Wisconsin Law Review:1062-1102.

Willer, Dirk. 1997. Corporate Governance and Shareholder rights in Russia. CEPR Discussion Paper. London: School of Economics.

Zweigert, Konrad, and Hein Kötz. 1984. Einführung in die Rechtsvergleichung auf dem Gebiet des Privatrechts. Tübingen: J.C.B. Mohr Paul Siebeck. 